\title{
Sideshows at the Center British Campaigns in the Middle East during the Great War
}

\author{
Priya Satia
}

The Great War earned the title "World War" because of its kaleidoscopic nature, its fronts stretching east and west, across land and sea. And yet, our memory and cultural experience of the conflict is closely tied to the western front, a fittingly tragic setting for exploring the ironies and horrors of the modernity the war represented. ${ }^{1}$ Certainly, other fronts have had their due in particular contexts-Gallipoli was critical to the making of Australian national identity, for instance-but most remain sideshows in scholarship and public memory. It is perhaps understandable that the western front should have become a synecdoche of the globe-girdling affair of 1914-1918, given the enormous toll of human life lost there and the immense cultural production that arose from it. Still, that narrow focus betrays a certain parochialism; recent scholarly trends impel us to interrogate the extent to which it is the product of Eurocentrism and to explore how a wider perspective might change our understanding of the war. Our limited geographical focus is especially odd given that the war was itself an apocalyptic expression of spatial notions that had been evolving since the fin de siècle: "Modern war required a multiplicity of perspective," writes Stephen Kern, manifested by multiple fronts and the lack of a clearly identifiable center. Each space of the war was equally important. ${ }^{2}$ Its designation as a "world war" spoke not only to its geography but to its cultural meaning and significance.

1. Hew Strachan has shown that the war was truly global from the start: Strachan The First World War, vol. 1, To Arms (Oxford: Oxford University Press, 2003).

2. Stephen Kern, The Culture of Time and Space, 1880-1918 (Cambridge: Harvard University Press, 1983), 300-301. 
In fact, Eurocentrism has structured our understanding of the Great War from the time of the conflict itself, when other theaters of combat were termed "sideshows" despite their often enormous scale and impact. Their marginalization was made easier, and necessary, by the ethical dubiousness of Entente powers' actions in them, which disrupts the tragic, self-destructive tenor of the western front story. Our silence about these sideshows is an artifact of initial wartime efforts to suppress scrutiny of those theaters: British activity in the Middle East was shrouded in secrecy to avoid arousing the ire of anti-imperialists, alerting Indians to the German call to jihad, and offending Arab allies. "Why is the Persian Gulf campaign ignored?" complained the Times in 1915, remarking that it was "the most successful campaign of all" and "as much a British war as the campaign in Flanders." ${ }^{4}$ As one Middle East expert foresaw in 1922, "The full story of the part Arabia played in the war remains to be written. It will be a stirring tale, full of romance and of all the glamour of guerilla warfare; it will also contain episodes of individual enterprise ... in what must surely be one of the most extraordinary epics ... in the Great War." ${ }^{5}$

Banishing knowledge of these other fronts has had important consequences for the way we have understood even the European experience of the war. Disillusionment with technology lies at the heart of British historians' conventional wisdom about the war's cultural significance: turn-of-the-century Europeans had great faith in technology as a facilitator of movement and advancement, and experienced a rude awakening when the unprecedented firepower and logistical constraints of industrialized warfare brought the conflict to a bloody standstill on the western front. Works like Paul Fussell's The Great War and Modern Memory and Eric Leed's No Man's Land associate trench warfare with a major cultural rupture, resulting in the birth of modernism, the ironic mode, and the decline of faith in Victorian ideals like progress and technology. ${ }^{6}$ This is all true, and yet leaves much unexplained. If the massive, technology-driven battles of the western front killed individual heroism, how do we account for the endurance of the heroic action genre in films and fiction? If technology's dark side was exposed by the

3. Priya Satia, Spies in Arabia: The Great War and the Cultural Foundations of Britain's Covert Empire in the Middle East (Oxford: Oxford University Press, 2008), 289.

4. "Why is the Persian Gulf Campaign Ignored?" and "The Middle East and the War," Times, September 10 and 22, 1915, respectively pp. 9 and 9.

5. Douglas Carruthers, "Captain Shakespear's Last Journey," Geographical Journal 59, no. 5 (1922): 321-44, here p. 321. On the scope and implications of the term "Arabia," see Satia, Spies in Arabia, 13-14.

6. Paul Fussell, The Great War and Modern Memory (London: Oxford University Press, 1975), ix; Eric J. Leed, No Man's Land: Combat and Identity in World War I (Cambridge: Cambridge University Press, 1981). On the limits of this cultural rupture, see Jay Winter, Sites of Memory, Sites of Mourning: The Great War in European Cultural History (Cambridge: Cambridge University Press, 1995), 2-5; Michael Paris, Warrior Nation: Images of War in British Popular Culture, 1850-2000 (London: Reaktion Books, 2000), 151-85; and Janet S. K. Watson, Fighting Different Wars: Experience, Memory, and the First World War in Britain (Cambridge: Cambridge University Press, 2004). On the technological aspects of the war, see John Terraine, White Heat: The New Warfare, 1914-18 (London: Sidgwick and Jackson, 1982). 
western front, why did the Second World War depend on an even greater embracing of technology? Finally, if Britain had lost faith in industrialism, why was World War I the turning point at which the colonies shook off the chains of industrial subordination? ${ }^{7}$ Recent confirmations of Britain's enduring industrial strength after the war render the cultural pessimism about technology even more intriguingwhy did it not impact industrial progress? $?^{8}$ Clearly the cultural bankruptcy of Victorian values is only part of the story. Manifold visions of technology and heroism emerged during the war, and an equally kaleidoscopic analysis of it might allow us to grasp their range.

In this article, I want to assess the contribution of experiences in the Middle East to Britain's wartime cultural transformation. I do not offer a full treatment of the Middle East campaigns and their local and global impact, a task well beyond my reach as a historian of Britain. Rather, I will show how mobilizing even just the British sources about those campaigns radically alters our understanding of the war's cultural legacy for Europeans, an understanding which until now has been too narrowly based on the western front. As the war wore on and the Middle Eastern campaigns met with greater success than the western front, Whitehall traded secrecy for propaganda about the achievements of its troops. Those stories, framed by the cultural outlook of experts on the region emerging primarily from upper-middle class, public-school backgrounds, leavened the harrowing news from France. The sideshows are thus essential to explaining why Britons remained committed to the war despite the death toll and the stalemate on the western front. The Palestine campaign was, in Eitan Bar-Yosef's words, "consciously staged by the British government as an exercise in propaganda, shaped, filtered and capitalized on in order to enhance the nation's morale." If, as Samuel Hynes claims, other fronts have simply not entered the "myth" of the war, ${ }^{10}$ this singularity of vision is more our own than that of postwar Britons. Witness, for instance, the entwining of the "Lawrence of Arabia" and western front myths in Robert Graves's Good-Bye to All That ${ }^{11}$ or the centrality of the myth of the air and desert wars in the pursuit of the Second World War, described by Hynes himself. Reintegrating the Middle

7. Daniel R. Headrick, The Tentacles of Progress: Technology Transfer in the Age of Imperialism, 1850-1940 (New York: Oxford University Press, 1988). On the myth of an antitechnocratic England, see David Edgerton, England and the Aeroplane: Militarism, Modernity and Machines (London: Penguin Books, 2013).

8. For a synthesis of the historiography, see David Edgerton, Science, Technology and the British Industrial "Decline," 1870-1970 (Cambridge: Cambridge University Press, 1996), $1-10$.

9. Eitan Bar-Yosef, "The Last Crusade? British Propaganda and the Palestine Campaign, 1917-18," Journal of Contemporary History 36, no. 1 (2001): 87-109, here p. 88. On the social milieu of the officers who produced these ideas about the Middle East, see Satia, Spies in Arabia, chap. 2.

10. Samuel Hynes, The Soldier's Tale: Bearing Witness to Modern War (New York: Allen Lane, 1997), 116; Bar-Yosef, “The Last Crusade," 108.

11. Robert Graves, Good-Bye to All That: An Autobiography (London: Jonathan Cape, 1929). On Lawrence, see John MacKenzie, “T. E. Lawrence: The Myth and the Message," in Literature and Imperialism, ed. Robert Giddings (Basingstoke: Macmillan, 1991), 150-81, and the literature cited in Satia, Spies in Arabia. 
East campaigns into our main narrative of the war will allow us to reconstruct how contemporaries understood it.

It will also help solve the particular mystery mentioned above-how heroism and faith in technology survived despite the news from France. If trench warfare produced a stalemate in France, the Middle East showed that it could still work, especially when supplemented by special operations, deceptions, and airpower in a manner that crucially shaped tactics in the next world war. If "no man's land" represented technology's desolation of nature into the "heart of darkness," ${ }^{2}$ in a colonial heart of darkness technology appeared in a vastly different light: a war of conquest was reconfigured as an international development effort, laying the groundwork for the trusteeship imperialism of the $1920 \mathrm{~s}^{13}$ If the situation in France raised doubts about the possibility of individual heroism, Arabia produced the single most famous action-hero of the early twentieth century, T. E. Lawrence. Britons who hoped war would release their country from decadence and complacency witnessed the shattering of this illusion on the western front; but they were treated to a narrative of compensation emanating providentially from the site of Armageddon itself. As the soldiers posted there fulfilled dreams of authentic experience, the British public glimpsed a shimmering vision of the Old World rising, like a phoenix, from the ashes of total war, stripped of its decadent veneer and anchored to the heroic image of Lawrence of Arabia and imperialism reinvented as development. ${ }^{14}$ The dominant view of the region and of the tactics suited to it were legacies of nineteenth-century Orientalism, but were given a new twist by twentieth-century fascination with the occult and futuristic warfare..$^{15} \mathrm{In}$ this cultural moment guerrilla warfare, for instance, was no longer considered the indefensible recourse of the uncivilized but a modernist reconception of warfare. Such evolutions provided a means of simultaneously embracing and looking beyond the culture of war, as Britons' imaginative geography of the conflict wed the country even further to imperial experience and identity. The cultural legacy of the war, the vision of technology, war, and empire that it offered, and the integration of that vision into emerging conceptions of "modernity" were much more complicated than current historiography admits. In what follows, I rely on letters and reports of British personnel and soldiers in the Middle East to explore views of technology and heroism in that region of the war. I also use popular wartime and postwar narratives

12. Kern, Culture of Time and Space, 301.

13. Priya Satia, "Developing Iraq: Britain, India and the Redemption of Empire and Technology in the First World War," Past and Present 197, no. 4 (2007): 211-55.

14. On the colonial hero as an ideal type at the turn of the century, see Edward Berenson, Heroes of Empire: Five Charismatic Men and the Conquest of Africa (Berkeley: University of California Press, 2011); Satia, Spies in Arabia, chap. 5. Captain Scott's polar adventures on the eve of the war and the contemporary adventures of a slew of travelers to the Middle East fueled British interest in this type of terrain, conceived as nearly extraterrestrial at a moment when geographers worried that little was left to "discover" on the earth. On Scott, see Max Jones, The Last Great Quest: Captain Scott's Antarctic Sacrifice (Oxford: Oxford University Press, 2004). On the belated nature of this heroic exploration, see Satia, Spies in Arabia, chap. 2.

15. Edward W. Said, Orientalism (London: Routledge and Kegan Paul, 1978). 
about the campaigns, often by the same figures, to show that perspectives from the Middle East had a measurable cultural impact at home.

\section{How the Middle East Campaigns Made Military History}

Two major campaigns were fought in the Middle East. The Mesopotamian campaign began as a small operation by the Indian Army to defend Indian frontiers and British interests in the Persian Gulf. Comprising around 240,000 men in 1914 and doubling by the end of the war, the Indian Army was commanded from Delhi and Simla. Its troops were deployed all over the world, including on the western front, but its largest force abroad was Indian Expeditionary Force D in Mesopotamia. Once at the Gulf, Force D rapidly advanced north in an effort to shore up British possessions in the region. After an ill-fated attempt at taking Baghdad forced them into a disastrous retreat to Kut late in 1915, the campaign was taken over by the War Office in London. Following the capture of Baghdad in October 1917, Force D routed the Turkish Army near Mosul. In the second campaign, further to the west, troops guarding the Suez Canal embarked on an offensive assault in the Sinai Peninsula and then into Palestine and Syria, absorbing the remnants of the Gallipoli campaign into an enlarged Egyptian Expeditionary Force and coordinating its push north with the Arab Revolt. ${ }^{16}$

The distinct features of the military history of these campaigns-deception tactics, irregular warfare, and heavy reliance on airpower-set them apart from the typical image of fighting during the First World War-in some cases by design, as we shall see. That military history had a great cultural and political significance for contemporary Britons. From the start, these campaigns were strangely mobile and creative affairs in a war known for the Sisyphean struggles of soldiers and the torpidity of generals. ${ }^{17}$ General Edmund Allenby's ability to coordinate "infantry and cavalry, artillery and Air Force, Navy and armoured cars, deceptions and irregulars," earned Lawrence's hard-won praise, and contemporaries in general deemed the Middle Eastern campaigns precocious in that regard. Allenby's staff officer Archibald Wavell praised the inventive use of "almost every form of

16. David Fromkin, A Peace to End All Peace: The Fall of the Ottoman Empire and the Creation of the Modern Middle East (New York: Avon Books, 1989); Jeremy Wilson, Lawrence of Arabia: The Authorised Biography of T. E. Lawrence (London: Heinemann, 1989); Matthew Hughes, Allenby and British Strategy in the Middle East, 1917-1919 (London: Frank Cass, 1999); Malcolm E. Yapp, The Making of the Modern Near East, 1792-1923 (London: Longman, 1987); Arthur J. Barker, The Bastard War: The Mesopotamian Campaign of 1914-1918 (New York: Dial Press, 1967); Albert Hourani, The Emergence of the Modern Middle East (London: Macmillan, 1981); John Fisher, Curzon and British Imperialism in the Middle East, 1916-1919 (London: Frank Cass, 1999); Elie Kedourie, England and the Middle East: The Destruction of the Ottoman Empire, 1914-1921, 2nd ed. (Hassocks: Harvester Press, 1978).

17. On the origins of the tactics used on the western front, see Tim Travers, The Killing Ground: The British Army, the Western Front and the Emergence of Modern Warfare, 1900-1918 (London: Allen and Unwin, 1987). 
operation in almost every variety of climate and terrain." In the amphibious Mesopotamian campaign, noted the war correspondent Edmund Candler, "All the five arms of the Force-the Navy, Cavalry, Infantry, Artillery, and Flying Corpswere working together in a way that was new in war." ${ }^{18}$ It was only in the Middle East that "mobility was given opportunity, and the opportunity taken," the military theorist Basil Henry Liddell Hart observed. The British charge 350 miles north beyond Aleppo at the end of the Palestine campaign in 1918 was one of history's most stupendous cavalry actions, precipitating "the end of the greatest war that the world has ever known," in the assessment of the Journal of the Royal United Services Institute-even if, as we know, the war was won and lost on the western front. Deception, irregular warfare, and airpower, which have become basic to modern warfare, achieved their greatest development in the Middle East. This exceptionalism was the product of Middle East commanders' "ever-readiness ... to get along with their war by every piece of craft and cunning they could think of." 19 And that attitude was the product of a cultural outlook: Orientalism shaped British tactics and interpretations of the war in the Middle East.

For British troops, the Middle East offered "release" from the killing fields of France into fabled locales. ${ }^{20}$ "Those who have experienced war in France only do not know what war is," declared one soldier; in Mesopotamia, the "funny feeling [of] being alone ... in the desert," with "these bloody arabs coming in from nowhere," offered the epitome of warfare, with all its sense of myth and individual quest. ${ }^{21}$ "In exile from the world," the "Invincibles," as Force D was dubbed, fought "war as we used to imagine it," with the old, "humane" implements—the "good old fighting" that had vanished from France. They proved that "in the right place war even to-day can be a romance." "Would that the whole war could be fought in the desert lands," pined another soldier. Comparatively poor living conditions and supplies made their "sideshow" feel all the more like a penance promising expiation, especially since the one considerable advantage was that "one was not being shot at." Perhaps alone among that sacrificial generation, many soldiers who fought in the region fulfilled their hopes for adventure and their quest for authentic experience, especially after experiencing war in France. ${ }^{22}$

18. Thomas Edward Lawrence, The Seven Pillars of Wisdom: A Triumph (1926; New York: Anchor, 1991), 615; Archibald P. Wavell, Allenby: Soldier and Statesman (London: George G. Harrap, 1946), 195; Edmund Candler, The Long Road to Baghdad, 2 vols. (New York: Houghton Mifflin, 1919), 2:80.

19. Basil Henry Liddell Hart, "T. E. Lawrence": In Arabia and After (London: Jonathan Cape, 1934), 164; Q. L., "With the 13th Indian Cavalry Brigade in Palestine," Journal of the Royal United Services Institute (hereafter "JRUSI") 64/454 (1919): 232-45, here p. 245; Ferdinand Tuohy, The Crater of Mars (London: W. Heinemann, 1929), 210.

20. Satia, Spies in Arabia, 166.

21. Leeds University Library, Liddle Collection (hereafter "LULLC"), MES 020, Robert Stewart Campbell to his family, January 10, 1916.

22. Arthur Tillotson Clark, To Bagdad with the British (New York: D. Appleton, 1918), 2:47-49; Candler, The Long Road to Baghdad, 1:26 and 28; LULLC, MES 090 (Rolt 
They did so largely because they saw the region as an oriental land of fantasy-references to the Arabian Nights were on everyone's lips. Even Allenby felt "carried far beyond this world to something or some place I can't understand." 23 Lack of public knowledge about the campaigns fed the sense of being in a "strange land of mystery," a "fairyland" that was "hard to imagine, impossible to describe." Soldiers wondering about their "ultimate destiny" were grateful to be on an "interesting adventure." The excitement of arriving in "terra incognita" was amplified by the "wealth of legend, rumour, and history attached to this unknown country. ... Who could possibly resist some whisper of romance at the thought that we were heading towards the homeport of Sinbad the Sailor, and that beyond lay the ruins of great Babylon, Ur of the Chaldees, Nineveh of the Assyrians; a land crowded with great and terrible ghosts, full of strange history and mysterious legends?" A morale-boosting pamphlet on "The Land of the Two Rivers" attested that "Mesopotamia stirs the curiosity of the troops more perhaps than any other of the theatres of war." Officers lived in "a state of constant wonder." Even Graves, the poet and memoirist of the western front, sought transfer to the Middle East where his brother was an agent. Soldiers' letters home conveyed their fascination with the region, directing loved ones to by then classic accounts by British experts, works in which many anxious relatives were already immersed for their own edification. Some asked their families to send them new copies of these volumes, along with that ubiquitous prerequisite, the Arabian Nights. ${ }^{24}$

Baghdad became a military objective for several reasons, but the least controversial was that almost everyone at home had heard of it - which was more than could be said of any other place in Mesopotamia. As one soldier put it, "It was the Arabian nights." The very word was "a moral factor": soldiers despairing

23. Allenby to his wife, December 17, 1917, quoted in Brian Gardner, Allenby (London: Cassell, 1965), 163.

24. Sir Arthur Lawley, A Message from Mesopotamia (London: Hodder and Stoughton, 1917), 11, 34, and 91-92; LULLG, GS 0089, doc. 2, F. S. G. Barnett to his mother, March 10, 1917; H. Birch Reynardson, Mesopotamia, 1914-15: Extracts from a Regimental Officer's Diary (London: Andrew Melrose, 1919), 14-15 and 240-42; Army YMCA of India, "The Land of the Two Rivers," a document reprinted many times and often found among the papers of soldiers in Mesopotamia; LULLC, GS 0993, Lt. Col. L. A. LyndenBell, interview with Peter Liddle, TS, October 1977; LULLG, GS 1429, Sir Reginald Savory, "Recollections," undated TS; Clark, To Bagdad with the British, 2; LULLC, MES 082, box 1, correspondence between W. W. A. Phillips and his mother, April 1915; L. M. H., "An Arabian Night," Blackwood's Edinburgh Magazine, 203 (1918): 378-87, here p. 379; LULLG, EP 098, letters from Captain John Stevenson to his mother, 1917; James Saumarez Mann to his mother, March 15, 1920, in An Administrator in the Making: James Saumarez Mann, 1893-1920 (London: Longmans, Green, and Co., 1921), 234; British Library, London, India Office Records (hereafter “IOR”), Eur. MSS, F177/21, Emily Lorimer to her mother, March 31, 1917; LULLG, GS 1162, Joseph Napier to his mother, March 9 and 18, 1917; LULLC, MES 071, Lt. L. R. Missen, essay "Written for the 'Pelican,' the Perse School Magazine and passed by the editor to my mother, 19 April 1917"; St. Antony's College, University of Oxford, Middle East Centre Archive (hereafter “MECA"), Hogarth Papers, doc. 2, David Hogarth to Billy, February 19, 1917. 
of toiling uselessly in a vast "nowhere" now had a glamorous goal whose name "all knew and had known almost since we could remember." It conjured up memories of "flickering firelight and a quiet room and a gentle voice reading of old Baghdad. ... Who would not fight to get there and really see it?" Officers got goosebumps thinking of the ancient footsteps they were following in: "This was not ... 'miles on miles of F. A. [Fuck-All],' but a mine of historical interest." In the first year of the occupation, the Army YMCA of India distributed a tourist guidebook about Baghdad to "supply a demand increasingly evident." Laid out as a series of walking tours, it strove to enable "visitors" to see efficiently the city's many points of interest. ${ }^{25}$ In Palestine, too, British soldiers "travelled in the print of olden wars," explained Major Claude Jarvis. The final cavalry action occurred near "the battlefield of Issus (333 BC), where Alexander the Great first showed how battles could be won by bold and well-handled horsemen." ${ }^{26}$ If soldiers on the western front drew ironically and tragically on the quest motifs of (pseudo) medieval romances, ${ }^{27}$ those in the Middle East found them to be still-valid metaphors for their own experiences. Edward Gibbon's Decline and Fall of the Roman Empire was regularly consulted for parallels, as were the works of Xenophon, Herodotus, and Thucydides. ${ }^{28}$

Biblical history was part of this fascination. Troops in Mesopotamia sought out the Garden of Eden, Ezra's tomb, the Tower of Babel, Ur of the Chaldees, and other sites. The soldier Edward Kinch felt "immensely moved by the close contact with many Old Testament places and Legends," which produced "an affinity with the country ... quite unexplainable but nevertheless strong." The ranks reportedly sat around for hours with Bibles and maps working out natural explanations for what they had taken to be legends. Though not all were convinced, the experience of Biblical sites "brought to many ... the realization that the tales of the Old Testament were based on fact." There, affirmed a war correspondent, "you live the story of the Bible, and you do not wonder in the least if it is true; you know it is." Palestine was likewise "far from being a strange country": soldiers looked forward to seeing places they had learned of "at our mother's knees," where they felt "at home and not lost as ... in Gallipoli and Salonika." God's palpable presence was a "splendid incentive."

25. LULLC, GS 0993, Lt. Col. L. A. Lynden-Bell, interview with Peter Liddle, undated TS, October 1977; Reynardson, Mesopotamia, 240-42; LULLC, GS 1429, Sir Reginald Savory, "Recollections," undated TS; LULLC, MES 094, Army YMCA of India, "Baghdad: The City of the Caliphs," 1918. On the selection of Baghdad as a military objective, see Peter Morris, "Intelligence and Its Interpretation: Mesopotamia 1914-1916," in Intelligence and International Relations, 1900-1945, ed. Christopher Andrew and Jeremy Noakes (Exeter: University of Exeter Press, 1987), 90.

26. Claude S. Jarvis, Arab Command: The Biography of Lieutenant-Colonel F. G. Peake Pasha (London: Hutchinson, 1942), 50; Wavell, Allenby, 245-46.

27. Stefan Goebel, The Great War and Medieval Memory: War, Remembrance and Medievalism in Britain and Germany, 1914-1940 (Cambridge: Cambridge University Press, 2007); Fussell, The Great War and Modern Memory, 135-44 and 154. 
Major Vivian Gilbert admired the "cockney soldiers" open displays of piety as he shed his own "outer layers of ... decadent refinement." Every circumstance heightened the "romantic setting," observed another officer, and "prophecy after prophecy was fulfilled." They fought over country that "enshrined the most sacred memories and traditions, whose familiar place-names stir the deepest emotion of all who read the dispatch," affirmed the Times. "Our eyes were often on the past," recalled Candler: "The arid tracts where our own troops and General Allenby's were fighting, and the desert between spanned the whole land of Holy Writ. ... We had a supply dump not a hundred yards from the ... spot where Jonah was cast up by the whale." Allenby's troops "used the[ir] Bibles as guide books to Palestine, and remarkably fine ones they turned out to be!" affirmed Gilbert. Even to the more secular minded, the Biblical austerity of Bedouin life offered an exemplary counterpoint to the decadence that had landed the British in the nightmare of the war. ${ }^{29}$

En route to Jericho and lacking any other information on the area, Gilbert planned the attack on Mickmash by studying the tactics used there by Jonathan according to the Book of Samuel. Allenby studied the Bible "with the passionate absorption of Cromwell's Ironsides, and ... based his plans on the study of the wars of Joshua." He devoured histories of the Crusades, "so convinced that in the unchanging East history would repeat itself that from the beginning he said that the decisive battle of the campaign would be fought at the Pass of Megiddo." Soldiers, too, expected war in such a place to be radically unlike that in France. And it was: officers considered it a form of cultural respect to approach action in the region with an originality and ethical nonchalance that would not have been tolerated in Europe. Those deployed with the Sharifian forces or serving as political officers in Mesopotamia drew on Edwardian notions of getting along in Arabia by mimicking the "Arab mind." "Leave your English friends and customs ... and fall back on Arab habits entirely ... to beat the Arabs at their own game," Lawrence advised. "The more unorthodox and Arab your proceedings, the more likely you are to have the Turks cold." They needed not the Englishman who became "more rampantly English" away from home, but a "subtle and insinuating" type who "directed men secretly." Officers took this brief seriously. Serving in Mesopotamia, Harold Dickson wrote to his mother that the Arabs spied on him constantly, and though "it is our policy to treat them as friends," he assured, "I meet cunning with cunning." The

29. MECA, Edward Kinch Papers, doc. 1/2, autobiographical notes, undated MS, p. 27; LULLC, GS 1429, Sir Reginald Savory, "Recollections," undated TS (my emphasis); Eleanor Franklin Egan, The War in the Cradle of the World: Mesopotamia (London: Hodder and Stoughton, 1918), 74-76, 232, and 242; Conrad Cato, The Navy in Mesopotamia, 1914 to 1917 (London: Constable, 1917), 17; Raymond Savage, Allenby of Armageddon (London: Hodder and Stoughton, 1925), 198; Owen Tweedy, Gathering Moss (London: Sidgwick and Jackson, 1967), 65-66; Vivian Gilbert, The Romance of the Last Crusade (New York: D. Appleton, 1924), 111-22, 180-86, and 235; Richard Meinertzhagen, Army Diary, 1899-1926 (Edinburgh: Oliver and Boyd, 1960), 22; "Allenby's Crowning Mercy," Times, December 31, 1918, 9; Candler, The Long Road to Baghdad, 2:198. 
representation of Arabia as a land of daring and intrigue rendered irrelevant the regard for social and cultural mores and legal conventions that constrained, or at least engendered doubts about, the activity of the British elsewhere. Here, perhaps for the first time, officers freely admitted, without recourse to euphemism, that they intrigued without scruple because the place itself provided a ready excuse for ungentlemanly behavior. They conspired with Ottoman subjects in the destruction of the Ottoman Empire, entering it "like sphinxes," in Lawrence's words. The ruthless disciplinary actions of British political officers were represented as episodes in the ever-unfolding epic of Arabian intrigue. ${ }^{30}$

This effort to adapt led to the invention of modern deception tactics. In the "haversack ruse" employed before the Third Battle of Gaza at the end of 1917, Allenby's intelligence chief Richard Meinertzhagen rode into no man's land, pretended to be hit by Ottoman fire, and dropped a sack of carefully faked "confidential" documents suggesting a British attack at Gaza. False wireless messages also hinted that activity in anticipation of the real attack on Beersheba was merely reconnaissance movement. David Lloyd George credited this ruse with the success of the battle; Allenby, with the success of the entire campaign. After this, Lawrence recorded, "deceptions, which for the ordinary general were just witty hors d'oeuvres before battle, became for Allenby a main point of strategy." Most importantly, before the Battle of Megiddo in 1918, the British concealed the main effort in the western sector and diverted Ottoman attention to the east: camps were built in the Jordan Valley and filled with unfit soldiers and fifteen thousand dummy horses; bridges were thrown up across the river; battalions marched east by day, returning secretly by night in trucks. Meanwhile, movement was actually going the other way as troops poured into camps near the coast, built extra-large in anticipation. Sand sleds created dust clouds to cover up activity or convey an impression of feverish animation as needed. Overt preparations were made for the imminent "transfer" of GHQ to Jerusalem-a hotel was vacated and signs, telephone lines, and the like installed. Lawrence and his "unwitting arab agents" were also used in this kind of ruse. ${ }^{31}$ The invention of modern deception tactics in Palestine has long been treated as a piece of military-historical trivia; it is time to consider how it fitted into the general approach to war in the Middle East and the impact of this approach, in turn, on the military and cultural history of the Great War.

These were the only successful modern deceptions of the war, the only attempt at using deception as a strategic principle in an entirely modern way. ${ }^{32}$ As Middle East Commander in World War II, Wavell drew on them when designing the

30. Wavell, Allenby, 162; Thomas Edward Lawrence, "Twenty-Seven Articles," Arab Bulletin 60 (1917): 347-53, article 20; Lawrence, The Seven Pillars of Wisdom, 195, 339, 346, and 381; MECA, Dickson Papers, box 1, file 3A, Dickson to his mother, February 17, 1915; box 1, file 4, March 13, 1916; box 2, file 1, February 14, 1916; Satia, Spies in Arabia, 137-43.

31. Liddell Hart, "T. E. Lawrence," 237 and 341; Satia, Spies in Arabia, 143-44. 
Battle of El Alamein, which in turn inspired the deceptions leading to the invasions of Sicily and Normandy. The Mesopotamia campaign was also full of "attack by indirection," "the ruse, the left hook." Major-General Percy Cox complained of the conventionalism of General Frederick Stanley Maude, who arrived to command the campaign after the siege of Kut-he was "purely a soldier ... without any previous experience of the East or of Orientals." Nevertheless, the initial attack against Sannaiyat, for instance, was a bluff covering the real assault along the Shatt-al-Hai, and many of the advances, including that on Khan Baghdadi, involved ruses. Others considered Maude a "great man for mystifying and misleading," who knew "how much he could accomplish by surprise." 33

Deception is typically used as a way of multiplying the forces of a disadvantaged combatant. In Palestine, however, where the British had a preponderance in strength, it was clearly inspired by other considerations. The intelligence community's fascination with the region's past extended to studying the earliest recorded military deceptions, before these kinds of tactics came to be seen as dishonorable in the Middle Ages. Allenby found instruction in chapter seven of the Book of Judges, which recounts the night attack by Gideon's three hundred: as Wavell would remark during the next war, "The lessons it teachesthe value of discipline, the need for personal reconnaissance, the moral effect of surprise-are applicable to any night attack to-day." Allenby's staff was struck by a passage in Sir George Adam Smith's Historical Geography of the Holy Land (1894): "Everything conspires to give the inhabitants easy means of defence against large armies. It is a country of ambushes, entanglements, surprise ... where the essentials for war are nimbleness and the sure foot, the power of scramble and of rush." Deception seemed fitting and even fated in this romantic land. "After thousands of years," it was felt, "the tactics of Saul and Jonathan were repeated with success by a British force." ${ }^{35}$

The first British attempt to hide an entire offensive thus took place in a desert. The lack of cover initially seemed to make surprise impossible. "Where we are had, is by the flatness of the country," complained Dickson. "For miles and miles it is like a table and ... the Enemy ... can see us coming hours before." But the desert's natural subterfuges also inspired: "There is not a cavalry regiment ... which has not at some time or other mistaken sheep for infantry," noted Candler. Soldiers

key Middle East personnel were sent to Europe later in the war to encourage the use of deception there (see below, p. 92).

33. Wavell, Allenby, 195; Bruce A. Watson, Desert Battle: Comparative Perspectives (Westport: Praeger, 1995), 106-8; Cox to the India Office and the government of India, May 25, 1918, quoted in Philip Graves, The Life of Sir Percy Cox (London: Hutchinson, 1941), 223; Frederick Vavasour Broome Witts, "The Passage of the Tigris at Shumran, 23rd February, 1917," JRUSI 68/471 (1923): 447-56, here p. 447.

34. Wavell, Allenby, 235 and 187 (quoting Smith); Savage, Allenby of Armageddon, 198. Allenby also drew on certain aspects of the relief of Kimberley (in present-day South Africa) during the Boer War.

35. Edmund Dane, British Campaigns in the Nearer East, 1914-1918: From the Outbreak of War with Turkey to the Taking of Jerusalem (London: Hodder and Stoughton, 1919), 2:226-27. 
on reconnaissance became lost, visual signaling failed, and ranging was impossible in "a fairyland that danced and glimmered." The men could scarce observe their own fire. Even the mistakes leading to the disaster at Kut were partially excused by "the deception emanating from desert mirages." 36 The soldier Martin Swayne described how "hostile Arabs, knowing the mirage areas, would get into them and make ranging impossible." Vanishing in and out of a mirage "like a minuet," they used it for surprise; when approached, they "disappeared into the mirage as if the ground had opened and swallowed them up," recounted a reconnaissance officer. "No sooner had a group vanished on our right, than another would appear like a cinema picture on our left, also to vanish and have its place taken by another elusive spectre, perhaps straight ahead. So, chasing phantoms, we continued." As if by "magic," when he had seen "nothing for hours and hours," attested Dickson, Arabs would suddenly attack "from behind mirages ... employing a thousand and one other stratagems." He described in a letter the "élan dash mystery and picturesqueness" of the "lightening" warfare of these "whil o the whisps [sic]":

Picture ... a perfectly flat sandy desert. ... A white man would see not an atom of cover, but these desert men make use of these weird folds in the ground in diabolical fashion.... An officer ... scanning the horizon for a sign of the enemy is in the foreground, his halted squadron completes the picture. Suddenly ... in the far distance, commences the dust storm. ... It strikes in full force at last and God in Heaven what comes to. Five thousand howling fiends, wild desert arabs, with faces wrapped up all except the eyes come with the storm. Like a whirlwind they are upon you - flowing robes, firing from the saddle whilst at full gallop, never pausing a moment on they come. Before you can count sixty they have surrounded you. ${ }^{37}$

And then, he added, "they simply disappear no one knows where." The Bedouins could also invent cover when under attack from the air: spread out, each "quite still beside his camel," after "withdrawing into the stony wadis ... they lay down on the shady side of their crouching 'mounts,' and from the air could not be distinguished from the surrounding rocks." In such "subtle ruses" could be found "lessons ... of the greatest interest," a war correspondent advised. Arab warfare was a lesson in flexibility: in flood-prone southern Mesopotamia, their quick mounting of boats and rebuilding of villages inspired Force D's floating air bases and patrol boats. Perhaps, one soldier speculated, the desert "sharpened ... ingenuity." ${ }^{8}$

36. MECA, Dickson Papers, box 1, file 3A, Dickson to his mother, December 29, 1914; Candler, The Long Road to Baghdad, 1:111; Edward J. Thompson, The Leicestershires beyond Baghdad (London: Epworth Press, 1919), 75; Tuohy, The Crater of Mars, 165-66.

37. MECA, Dickson Papers, box 1, 2nd booklet, Dickson to Greene, March 10, 1915. 38. Swayne, In Mesopotamia, 68; Candler, The Long Road to Baghdad, 1:110-11; Black Tab, On the Road to Kut: A Soldier's Story of the Mesopotamian Campaign (London: Hutchinson, 1917), 571; MECA, Dickson Papers, box 1, file 3A, Dickson to his sister, March 12, 1915, and to his mother, March 6, 1915; Dane, British Campaigns in the Nearer East, 2:153, and 1:v; Sam Cottingham Rolls, Steel Chariots in the Desert: The Story of an Armored-Car Driver 
The Bedouin ability to turn to advantage the very phenomena that seemed to render regular modern warfare impossible was at once enchanting, threatening, and instructive. They posed a "new enemy question," and their methods seemed bafflingly modern to a British army ordinarily sure of its own supreme sophistication. "We can take no risks with these men of mystery," avowed Dickson-"We understand the Turk but I'm blessed if we can quite fathom our latest enemies." Lawrence admired Arab forces in the west of the region, "riding about in small parties, tapping the Turks here and there, retiring always when the Turks advance, to appear in another direction immediately after," causing "the enemy not only anxiety, but bewilderment." Far from seeing these strategies as primitive, British Arabists concluded that "the man who uses his wits ... is most likely to win." ${ }^{39}$ Their forces would beat the Arabs at their own game. Experience would arm them against Bedouin deceptions- "We of us who have been here some time are beginning to grasp it slowly," attested Dickson, "it is the new Regts that are continually being fooled"-but they also learned to construct their own "strategic mirage." Instructions in counter-espionage morphed into lessons about tactics. False camps were a case in point. Where billeting was primarily in camps, explained the intelligence officer Frederick Leith-Ross, "tent-checks" were crucial: any absence of transport animals, wheel-marks, or tracks would awaken "the suspicions of the Intelligence officer." "The possibility of false camps, erected with the idea of misleading the opposing side as to the location or strength of troops in any area, must not altogether be lost sight of," he concluded. "A clever piece of bluff of this sort will stand a good chance of success if not tried too often."

Disinformation was central to deception. Observing that "the Turks seem unable to discriminate the true from the false, out of ... news ... brought them by the local Arabs," Lawrence determined to spread faulty information about British activities. Leith-Ross attested that it was not difficult "in a country like Iraq to start the circulation of misleading and inaccurate information with a view to such information reaching the enemy." The War Office's postwar intelligence handbook proclaimed that in "semi-civilised" regions, "races are able to transmit news to each other over great distances with astounding rapidity and by means which are sometimes difficult to explain." This offered certain advantages in terms of the "ease with which false information can be spread"- "an effective

with the Duke of Westminster in Libya and in Arabia with T. E. Lawrence (London: Jonathan Cape, 1937), 170.

39. MECA, Dickson Papers, box 1, file 3A, Dickson to Greene, March 10, 1915; Firestone Library, Princeton University, Arab Bureau Papers, FO 882, Lawrence to Wilson, January 8, 1917, Arab Bulletin 42 (February 15, 1917), 77; Rolls, Steel Chariots in the Desert, 170.

40. MECA, Dickson Papers, box 1, 1st booklet, Dickson to Greene, February 7, 1915; Liddell Hart, "T. E. Lawerence," 245; John Presland, Deedes Bey: A Study of Sir Wyndham Deedes, 1883-1923 (London: Macmillan, 1942), 275; National Army Museum, London (hereafter "NAM"), ARC 1983-12-69-10, Leith-Ross Papers, "Tactical Side," undated TS, 4-7. 
weapon," since "although most irregulars are adepts at setting snares, they are seldom sufficiently wary to avoid them." ${ }^{41}$ Allenby thus gave "carte blanche to his Intelligence Staff to ... bamboozle the Turk to the limit of their art," while Meinertzhagen searched out his opponents to "provide them with ... carefully doctored falsehoods. In his hands, intelligence became almost a weapon of attack." So impressive was their success that Meinertzhagen and Guy Dawnay were shunted to the western front where the intelligence establishment "was in a groove and stagnant." 42

Similarly, irregular warfare came into its own in the Middle East when the British coopted the tactics of "wild desert horsemen" to create the first "special operations force." The military establishment had long viewed guerrilla warfare as the unsophisticated and vexatious warfare of tribes, Boers, and other backward peoples. With the Arab revolt, it was naturalized as a modern, British tactic. Instead of dismissing Arab support of the enemy as "tribal harassment," British observers now recognized it as "a kind of irregular arm for the Turk." ${ }^{3}$ They were awed by the way "a horde of Arabs emerge from the dark masses and spread in a fanlike movement over the whole horizon." "These irregulars are eternally swooping about for no apparent reason," Candler mused, "unless it be bravado or the instinct of the kit." The "men of mystery" in billowing robes could not endure ordinary command structure, thought Lawrence: "The Hejaz war is one of dervishes against regular troops-and we are on the side of the dervishes. Our text-books do not apply to its conditions at all." This was no casual assessment, but an article of faiththe twenty-second of his "Twenty-Seven Articles" on working with Arabs, which remain influential in counterinsurgency practice today: "The Hejaz confounds ordinary tactics. Learn the Bedu principles of war." ${ }^{44}$ However indebted to a romantic sensibility, Lawrence presented this finding as the product of careful reflection: "Savage warfare seems never to have been thought out in English from the savage point of view, and the Arab revolt would have been a great opportunity for a thinker to test its possibilities on a grand scale. Our war was so odd and so far away that coy Authority left us to ourselves." He determined to "prove irregular war or rebellion to be an exact science, and an inevitable success." His object was not to merely imitate Bedouin practice, but, as always, to improve it: "Only by

41. The National Archives, London (hereafter "TNA"), Arab Bureau Papers, FO 882, T. E. Lawrence, "The Occupation of Akaba," Arab Bulletin 59 (August 1917): 231-32; Lawrence, The Seven Pillars of Wisdom, 385; NAM, Leith-Ross Papers, "Secret Service or Intelligence," 11 (my emphasis); TNA, WO 287/228, War Office, Manual of Military Intelligence in the Field (London: HMSO, 1922).

42. Tuohy, The Crater of Mars, 210-11; Meinertzhagen, Army Diary, 243 (September 30, 1918). Meinertzhagen, an intelligence officer, drew partly on ruses he had invented (also against Arabs) in East Africa.

43. MECA, Dickson Papers, box 1, file 4, Dickson to his mother, March 6, 1915; Candler, The Long Road to Baghdad, 1:112 and 2:25.

44. Ibid., 1:111; TNA, FO 882, T. E. Lawrence, "Military Notes," Arab Bulletin 32 
graduating in the Beduin [sic] school could [I] gain the competence and the prestige to modify its practice." The result was "The Evolution of a Revolt," an enormously influential essay on military tactics published in the first number of the postwar Army Quarterly. ${ }^{45}$

Mobility was at the heart of his theory, marking an implicit contrast to the western front, where commanders continually failed in their efforts to restore mobility to the war. Rather than fixed, immobile armies, Lawrence reasoned, "we might be like vapour," "an influence, an idea, a thing intangible, invulnerable, without front or back, drifting about like a gas." He pointed to the Bedouin's "assiduous cultivation of desert-power," their ability to control with scattered parties "the desolate and unmapped wilderness ... of Arabia." Their small number made them "the most elusive enemy an army ever had." Arguing strenuously against the formation of regular Arab forces at fixed positions, he explained that it was not attack itself, but the threat of attack that arrested the enemy-his irregular troops had kept a Turkish force holed up in Medina without doing anything "concrete." Their threat was coextensive with the desert: "Our war should be a war of detachment," Lawrence concluded. "We were to contain the enemy by the silent threat of a vast unknown desert, not disclosing ourselves till the moment of attack." The purpose was not to engage the Turks but to impress them "with the fact that behind the Beduin screen lies an unknown quantity." In Arabia, "space [was] greater than the power of armies." "Retained with the army in Palestine this handful would have been merely a drop in the ocean," agreed Liddell Hart. But "sent into the desert they created a whirlpool that sucked down almost half the Turkish army." 46 The Indian Army officer Norman Bray affirmed that Arab irregulars were "far more powerful than at first appears," their strength deriving from their ability to deny the enemy a target. Ever-renewable, they could be dispersed but never destroyed: "Given a rallying point they will appear again as strong as ever." With the desert for camouflage, they appeared as a massive "national" rising. Irregular warfare depended on bluff and was tied to deception. In the desert, small actions produced disproportionate impact; rumor magnified them until they assumed the epic proportions British Arabists thought fit for Arabia. ${ }^{47}$

The contrast with the western front, where forces were continually decimated and never scattered, was obvious. Others echoed these opinions, praising the

45. Thomas Edward Lawrence, "The Evolution of a Revolt" [1920], reprinted in Lawrence, Oriental Assembly, ed. A. W. Lawrence (London: Williams and Norgate, 1939), 103-34, here pp. 112-15 and 133-34; Wilson, Lawrence of Arabia, 629. Much of Lawrence's article reappeared in The Seven Pillars of Wisdom.

46. Lawrence, "The Evolution of a Revolt," 112-13, 116, and 122; Lawrence, The Seven Pillars of Wisdom, 192 and 196; Lawrence to his family, February 12, 1917, in The Home Letters of T. E. Lawrence and his Brothers, ed. M. Robert Lawrence (Oxford: Blackwell, 1954), 335; Lawrence to Clayton, August 27, 1917, in Selected Letters of T. E. Lawrence, ed. David Garnett (London: World Books, 1941), 120; Liddell Hart, “T. E. Lawerence,” 375. 47. Bray, November 8, 1916, in Arabian Report no. 18, undated; Satia, Spies in Arabia, chaps. 2 and 4. 
democratic, improvised, and refreshingly unbureaucratic nature of the Arab revolt. ${ }^{48}$ Unlike the troops in France, the Arabs' circumstances "were not twice similar, so no system could fit them twice," and their enforced organizational "diversity"- their strength depending on "whim"- threw enemy intelligence off. They went about in bands, their "minds not bodies" arranged in battle order; even they themselves "had not the smallest idea of [their] strength at any given moment." Without formal discipline, their "only contract was honour," making their war "simple and individual," their "ranks a happy alliance of commanders-in-chief." Even among the British contingent, the large number of officers so diluted the rank and file that "rank fell into abeyance." In their ragged ensemble of drill shorts, open-necked shirts, kefiya, and heavy army boots without socks, they were the "worst-looking soldiers in the British army," a subaltern boasted, and thus fit for the work at hand. In the Middle East, the heroic style of the "gifted amateurs" who had built up the empire merged with modern soldiering, offering a way out of "the horrible de-humanisation" of contemporary warfare. Visiting Cairo from Mesopotamia, the political officer Gerard Leachman found "an absolutely new world of soldiering." Lawrence was also struck by the anomaly of his own role: "the position I have is such a queer one-I do not suppose that any Englishman before ever had such a place." 49

The British were well suited to such tactics, Lawrence assured, for "nearly every young Englishman has the roots of eccentricity in him." This was a vision of Englishness grounded in his upper-middle class, public-school background, the very stratum that contemporaries felt had suffered disproportionate casualties, robbing the country of its predestined elite, the lost generation. Happily, Arab tactics were "like naval warfare ... in their mobility, their ubiquity, their independence of bases and communications ... with a sure retreat always behind them into an element which the Turks could not enter." Military historians have generally followed Lawrence and Liddell Hart in domesticating irregular warfare as a quintessentially "British way in warfare." Meinertzhagen called Lawrence's theory a "prototype of what may become a commonplace in the future wars," foreseeing "no reason why every army in the future should not have an element of highly trained regular guerrillas as part of their normal organization." For

48. Storrs, circa December 1916, quoted in Wilson, Lawrence of Arabia, 342; TNA, FO 686/6/Pt.1, Intelligence report, December 28, 1916; Candler, The Long Road to Baghdad, 1:111; Presland, Deedes Bey, 179; Hubert Young, The Independent Arab (1933; repr. Piscataway: Gorgias Press, 2007), 162.

49. Lawrence, The Seven Pillars of Wisdom, 195, 339, and 381; Lawrence, "Twenty-Seven Articles"; Lawrence, "The Evolution of a Revolt," 128-31; Lawrence, The Seven Pillars of Wisdom, 340; Rolls, Steel Chariots in the Desert, 158; LULLC, MES 020, Robert Stewart Campbell to his family, January 10, 1916; Alma J. Plotke, Imperial Spies Invade Russia: The British Intelligence Interventions, 1918 (Westport: Greenwood Press, 1993), 185; Basil Henry Liddell Hart, The British Way in Warfare (New York: Macmillan, 1933); Hynes, The Soldier's Tale, 121-22; Leachman, quoted in Harry V. F. Winstone, Illicit Adventure: The Story of Political and Military Intelligence in the Middle East from 1898 to 1926 (London: Jonathan Cape, 1982), 299; Lawrence to his family, January 31, 1917, in The Home Letters, 334. 
Lawrence's comrades, much of the value of his contribution lay in its promise of restoring vitality and individuality to warfare: "Irregular war is far more intellectual than a bayonet charge," he insisted..$^{50}$ This kind of combat had vanished from the war on the western front; in their efforts to resurrect the mobility of older warfare, Lawrence and his peers were consciously inventing something totally new and yet typically British.

Lawrence's objective was also a less deadly modern warfare. Since Arabian ambitions were "geographical," "killing Turks" would serve no tactical purpose, he explained. Victory "lay not in battles, but in occupying square miles of country." In a typically modernist move, he attempted to see beyond a war of attrition, fixed positions, and massive chains of supply by reaching back to the medieval past. (The lieutenant-colonel Walter Stirling opined that Lawrence "would have been more at ease in the period of the early Italian Renaissance or possibly two hundred years hence.") Deeming "empirical practice" and canonical military theorists of the West like Napoleon Bonaparte, Ferdinand Foch, and Carl von Clausewitz irrelevant, he turned to campaigns he had studied "step by step"-those of "Hannibal and Belisarius, Mohammed and the Crusades!"-searching for "an immediate equation between my book-reading and our present movements." Despite his invocation of the Crusades and their bloody conflict, however, for Lawrence's colleague Alec Kirkbride "his ideal of waging war" was actually "based on the professional condottieri of medieval Italy" in its insistence on gaining "one's objectives with a minimum of casualties on both sides." Lawrence himself was proudest "that I did not have any of our own blood shed. All our subject provinces to me were not worth one dead Englishman." To be sure, the Arab revolt itself was far from bloodless. While projecting an image of train-raiding as "the most amateurish, Buffalo-Billy sort of performance," Lawrence confided darkly to others, "I hope when this nightmare ends that I will wake and become alive again. This killing and killing of Turks is horrible." He explained the Tafileh massacre as "an exception in my practice, undertaken in bad temper as a sardonic jest," throughout which he was "quoting to myself absurd tags of Foch and the other blood-fighters, and ... parodying the sort of thing they recommended. ... Killing Turks was no part of our business." ${ }^{51}$

50. Lawrence, “The Evolution of a Revolt," 122-23 (my emphasis); Plotke, Imperial Spies Invade Russia, 185; Liddell Hart, The British Way in Warfare; Hynes, The Soldier's Tale, 121-22; Hew Strachan, "The British Way in Warfare Revisited," Historical Journal 26, no. 2 (1983): 447-61; Richard Meinertzhagen, Middle East Diary, 1917-1956 (London: Cresset Press, 1959), 41 (January 10, 1938).

51. Lawrence, "The Evolution of a Revolt," 108-9, 111, and 121; Walter Francis Stirling, Safety Last (London: Hollis and Carter, 1953), 84; Kirkbride to Liddell Hart, after 1962, quoted in John E. Mack, A Prince of Our Disorder: The Life of T. E. Lawrence (Boston: Little, Brown, 1976), 239; Thomas Edward Lawrence, "The Suppressed Introductory Chapter for Seven Pillars of Wisdom," in Oriental Assembly, 135-48, here p. 144; Lawrence to Stirling, September 25, 1918, quoted in Wilson, Lawrence of Arabia, 447; Lawrence to E. T. Leeds, September 24, 1917, and to Archibald Becke, December 28, 1929, both in Selected Letters of T. E. Lawrence, 124 and 433-34. Guy Dawnay, the "brain behind the titular chief," was a student of Greek history, a poet, and a reputed eccentric whose prototype, Compton Mackenzie avowed, "must be sought in a Trojan 
Lawrence's professed "horror of bloodshed" and attraction to a warfare of evasion fit neatly with the romance of war in Arabia. "I love the preparation, and the journey, and loathe the physical fighting," he told a friend. "Disguises, and the prices on one's head, and fancy exploits are all part of the pose." Killing was a kind of decadence, the ultimate debauchery and the very sort of thing from which he sought escape in Arabia. Austerity had become a military as much as an aesthetic objective: "The Arab appealed to my imagination," began his explanation of his tactics, "The old, old civilization ... refined itself clear of household gods ... which ours hastens to assume. The gospel of bareness in materials is a good one, and it involves apparently a sort of moral bareness too. ... This is a very long porch to explain why I'm always trying to blow up railway trains and bridges." "We win hands down if we keep the Arabs simple," he explained. "To add to them heavy luxuries will only wreck their show, and guerilla $[s i c]$ does it. It's a sort of guerre de course, with the courses all reversed. But the life and fun and movement of it are extreme." Large numbers of regular forces were futile, Lawrence argued, observing that the Turkish Army lost its "efficiency for rough-and-tumble work" the more it was "improved" by the Germans. ${ }^{52}$

Many efforts were made to link the revolt in the Arabian Peninsula with a similar movement in Mesopotamia. But anxiety about encouraging Arab belligerence, given Britain's ambition to remain in the region, held Cox back. On Maude's death at the end of 1917, the chief of the Imperial General Staff urged General William Marshall to launch an Arab revolt with Cox's guidance. But Cox remained skeptical of its practicality given the fierce competition with the Turks for Arab loyalty; only enormous subsidies and masses of supplies would purchase local support. Still, the entire British effort in Mesopotamia was an exercise in disinformation: liberation camouflaged occupation.$^{53}$ Irregular tactics were also used on a smaller scale, with British agents raising "bands" of Arabs for pacification operations. Leachman especially was "a man of stratagems and surprises." Earlier in 1917, Cox had created a special force for intervention in Persia, prohibiting its control by Maude, who had "little appreciation for such novelties." ${ }^{54}$ Directed by General Lionel Dunsterville, this "mobile intelligence unit" raised an army of irregulars in the "utmost secrecy." In Basra and Baghdad, "these men hung together mysteriously in groups," wrote Candler, "and kept their own counsel about their future plans, of which, as a matter of fact, they knew very little indeed." Known as "Dunsterforce," they were a "band of adventurers into the unknown." For the

scene of the middle-ages ... perhaps in the corner of a picture by Crivelli where one of those small figures of warriors in the foreground seems to have detached itself from the crowded scene of chivalry behind and to have stepped forward from the past to commune with ourselves." Compton Mackenzie, Gallipoli Memories (London: Cassell, 1929), 96-97. 52. Lawrence to Newcombe, January 17, 1917, quoted in Wilson, Lawrence of Arabia, 351 (my emphasis); Lawrence to Vyvyan Richards, July 15, 1918, in Selected Letters, 244; TNA, FO 882, Lawrence, "Military Notes," Arab Bulletin 32, 1916.

53. Satia, Spies in Arabia, 156-57. 171. 
officer Reginald Savory, who volunteered for this "Hush Hush Army," it "combined the attractions of a military adventure and a crusade." Failing to find sufficient local support near the Caspian, Dunsterforce became the British military's first independent special forces unit, filling the gap the Russians left in North Persia by a kind of "moral camouflage" that took advantage of presumed local exaggeration of their meager strength. From there, irregular methods were exported into Russia. ${ }^{55}$

Irregular warfare and military deception depended on airpower. Control of the air was essential to confidence in the ability to conceal movements and effect surprise. Aircraft eased cooperation between bands of irregulars, since "a good pilot could ... land by the unit itself, give them their accurate position and inform the commander of the situation personally," explained Air Commander John E. Tennant. Cox prevented importation of the Arab revolt into Iraq but permitted the Royal Flying Corps (RFC) to replicate its train-wrecking exploits on the Baghdad railway. More generally, airpower addressed the unique requirements of "a moving battle over unchartered country." "Great as was the development of air power in the war on the western front," a Cabinet Paper of 1921 pronounced, it was "in more distant theatres ... such as Palestine, Mesopotamia and East Africa [that] the war has proved that the air has capabilities of its own. ${ }^{56}$ A squadron might be out of action by nightfall in France, but not in Arabia:

In this far land, where, without aerial observation, shot might as well not be fired; where maps were insufficiently accurate for troops to march by; and where, unless guarded and forewarned by the Air unit, men might walk into unknown and ambushed nullahs; it would have been a sorry tale to tell GHQ that there could be no flying on the morrow because of casualties to-day. The risks had to be taken and we backed our luck; it never failed. ${ }^{57}$

Commanders praised airpower's "enormous political possibilities," including its effect on morale and its potential for establishing officers with distant tribes. Aircraft in the Middle East impinged on intelligence in a way they never did on the western front. In an apparently unmappable desert, a bird's-eye view promised vision extending beyond the mirages, sandstorms, and horizonlessness that bedeviled ground observation. "Oh for some aeroplanes," pined officers in Mesopotamia. "If there was a country in the whole world eminently suited to

55. Ibid., 37; Keast Burke, ed., With Horse and Morse in Mesopotamia: The Story of Anzacs in Asia (Sydney: A. and N. Z. Wireless Signal Squadron History Committee, 1927), 104; Candler, The Long Road to Baghdad, 2:285-86; John E. Tennant, In the Clouds above Baghdad: Being the Records of an Air Commander (London: C. Palmer, 1920), 255; LULLC, GS 1429, Sir Reginald Savory, "Recollections," undated TS; Lionel Charles Dunsterville, The Adventures of Dunsterforce (1920; repr. London: E. Arnold, 1932), 3 and 68-69.

56. Tennant, In the Clouds above Baghdad, 38 and 60-61; TNA, AIR 2/940, Tennant to GOC RFC Egypt, December 30, 1916; TNA, AIR 1/426/15/260/3, Air Staff, "On the Power of the Air Force and the Application of that Power to Hold and Police Mesopotamia," 1920. For more on the RFC's work in the Middle East during the war, see Satia, Spies in Arabia, chap. 7.

57. Tennant, In the Clouds above Baghdad, 60-61. 
these machines this one is: Flat flat as your hand." Only aircraft would permit reconnaissance of the "dangerously deceptive" and "incalculable" landscape. Since "in Mesopotamian battles, little can be trusted that is seen," explained General Arthur G. Wauchope, "commanders are bound to rely on reports by aeroplane, messengers, and telephones." In the desert, aircraft made it "impossible for an enemy to alter his dispositions without discovery; the movement of a few tents ... can be spotted at once, and there are no woods or buildings in which to hide his men." In the Hejaz, too, they offered "the only means of overcoming the mirage" and the prevarications of natives-the information they furnished was "the only sort that can be relied on." Aviation also provided access to forbidden sites where British forces were not welcome (though in fact there were real limits on using aircraft in the desert). ${ }^{58}$ Aerial photography was developed in Cairo and Basra, meaning that before an attack hourly editions of maps could be produced and then distributed at the front by air. This technology "exerted its greatest influence in Mesopotamia," where aerial mapping was the "most advanced in the world." ${ }^{59}$ After the war, the Royal Air Force (RAF) issued a booklet on aeroplane photography, drawing on Mesopotamian examples to illustrate how to interpret signs like tracks, roads, and shadows. Aircraft signaling was also formalized for the first time in the Middle East. In short, the ways that aircraft were used in the region were generalized to produce a new science of airpower. ${ }^{60}$

Airpower took warfare in the Middle East to a mythic, almost Biblical level. As Turkish troops and transports retreated through the steep, narrow canyon of Wadi Fari'a in September 1918, spearheading the fall of Damascus, the RFC created the first ever aerial trap. There was no precedent "for such effective use of air superiority against ground forces in a maximal exploitation of the topographic conditions." The 1921 Cabinet Paper stressed this lesson in the "attack and dispersal of considerable bodies of ground troops." In his postwar account of events, Lionel Charlton directed students of airpower to this "solitary exception of the War," this "military disaster wrought exclusively by bombs," which he considered "a classic instance of the proper application of air power." "We were butchers," admitted the commander, "but ... all plans for retirement were completely upset by

58. TNA, WO 158/626, Geoffrey Salmond to CGS EEF, November 12, 1916, and "Note on Egypt force to Wingate," November 14, 1916; MECA, Dickson Papers, box 1, 3rd booklet, Dickson to Greene, February 7, 1915; Wilfred Nunn, Tigris Gunboats: A Narrative of the Royal Navy's Co-operation with the Military Forces in Mesopotamia from the Beginning of the War to the Capture of Baghdad (1914-17) (London: A. Melrose, 1932), 90; Arthur G. Wauchope, With a Highland Regiment in Mesopotamia, 1916-1917, by One of Its Officers (Bombay: The Times Press, 1918), 70; Tennant, In the Clouds above Baghdad, 35, 38-39, and 141; TNA, FO 686/6/Pt.1, Joyce to Wilson, March 24, 1917. On the limits to using aircraft and the many lethal errors they made, see Satia, Spies in Arabia, chap. 7. 59. TNA, AIR 10/1001, RAF, preface to "Notes on Aerial Photography, Part II: The Interpretation of Aeroplane Photographs in Mesopotamia," 1918; Michael Occleshaw, Armour Against Fate: British Military Intelligence in the First World War (London: Columbus Books, 1989), 61-62. On the agents' development of aerial photography in Egypt, see 
this attack from the sky. ... It is a new feature in war, and I do hope it can be made use of." Aircraft were used routinely to discipline tribes "both within and without the territorial boundaries which we control," who at times could "get out of hand and require a lesson" in the form of "an aerial raid with bombs and machine guns." They also substituted for the grueling night marches ordinarily used for attacking villages in "small wars," for, as Tennant found, "if a tribe got out of hand a raid could leave the next morning and bomb and machine-gun any village within a 100 -mile radius. Such immediate and drastic action inspired terror in the Arabs." This was the germ of the air-control regime that would be established in Iraq after the war. If irregulars configured the entire desert as a battlefield, aircraft did the same for the sky: appearing from nowhere and denying the enemy a target, their power stemmed as much from the awesome and ubiquitous threat they embodied as the actual destruction they inflicted. Unlike irregulars, however, the use of aircraft suspended all notions of "fair play" and reconfigured war as a visitation. ${ }^{61}$

How should we reconcile this carnage with Lawrence's efforts to banish killing from warfare? Military reasoning apart, it was bloodshed that made the Arab revolt an authentic experience for him: "The whole business of the movement seemed to be expressible only in terms of death and life." Lawrence and other British officers wanted the experience of the journey-quest, not mere adventure. For this, they had to come back having seen things. They enacted the role of the unknowing knight seeking escape but stumbling into great events that yielded real knowledge. Many who directed these campaigns went to the region with the hope of shaping their experiences in the image of epic literature, and Lawrence himself was famously attached to a dog-eared copy of Thomas Malory's Le Morte D'Arthur. ${ }^{62}$ Albert Hourani compellingly describes the Seven Pillars of Wisdom (1926) as "an attempt to write an epic work about activities that themselves had been moulded by a person who intended to write about them. Lawrence's ambition to write, his view of epic action based on his reading of ancient epics and of medieval romances, to some extent moulded his actions during the war. He later remoulded the epics in his book." Indeed, Lawrence admitted as much: "I had had one craving all my life-for the power of self-expression in some imaginative form. ... At last accident, with perverted humour, in casting me as a man of action had given me place in the

61. TNA, AIR 2/940, Tennant to GOC RFC Egypt, December 30, 1916; TNA, FO 882/VI, HRG/17/15, Pearson to Wingate, late February 1917; Dov Gavish, "Wadi Fari'a: The 'Valley of Death' in the Great War," Over the Front 15, no. 4 (2000): 360-66, here pp. 362-65; Lionel E. O. Charlton, Deeds That Held the Empire: By Air (London: J. Murray, 1940), 82-88; TNA, AIR 1/725/115/1, Salmond to a General, undated. See also Henry Robert Brooke-Popham, "The Air Force," December 3, 1919, JRUSI 65/457 (1920): 43-70, here p. 57; C. J. Mackay, "The Influence in the Future of Aircraft upon Problems of Imperial Defence," JRUSI 67/466 (1922): 274-310, here p. 302; Amyas E. Borton, “The Use of Aircraft in Small Wars," JRUSI 65/458 (1920): 310-19; NAM, Leith-Ross Papers, "Tactical Side," 8-9; Tennant, In the Clouds above Baghdad, 163. On air control, see Satia, Spies in Arabia, chap. 7; David E. Omissi, Air Power and Colonial Control: The Royal Air Force, 1919-1939 (Manchester: Manchester University Press, 1990).

62. Lawrence, The Seven Pillars of Wisdom, 550 (see also 308 and 633); Satia, Spies in Arabia, chap. 2. 
Arab Revolt, a theme ready and epic to a direct eye and hand, thus offering me an outlet in literature." Not only did aircraft, the "knights of the air," fit this aesthetic impulse, they operated in a Biblical land-pilots called Wadi Fari'a "The Valley of Death." From on high, the British pilot, a deus in machina, enacted the divine retribution he saw as fitting to such a place. ${ }^{63}$

Together, airpower, irregular warfare, and deception tactics distinguished the Middle Eastern theater of the war. Integrating these tactics and inventions with our image of the war of attrition in Europe helps make sense of the tactics relied on in the next world war, and of the cultural impact of the Middle Eastern campaigns during the interwar period.

\section{Technological Warfare, Empire, and Heroism}

As the western front shattered hope, the Middle Eastern fronts renewed it. If soldiers found mythic escape in the region, the British public found an opportunity to restore and redeem the Old World through the heroism of Lawrence of Arabia and the notion of technocratic development, which together sustained belief in the constructive nature of war and empire.

After the early silence on the Middle East campaigns, the Kut disaster put the Mesopotamian sideshow front and center before the British public. Exposure of the Indian government's blunders, namely the advance on Baghdad without adequate transportation and medical facilities, "kindled the feelings of the British public in a way that nothing else has done since the disclosures from the Crimea." The romance of the Arabian Nights was replaced with the image of a land of physical and moral trials. "Mesopotamia welcomes no man," a soldier brooded. "Adam and Eve might well have been excused in such a country." It was a no man's land by nature, a "treeless waste of swamp and desert," in Candler's words, and a "bleak emptiness to conquer." A report by the Mesopotamia Commission catalogued the "Physical and Climatic Peculiarities" of this autarkic wasteland. A naval captain described it as fundamentally remote and "far away from home, civilization, and comfort." For Candler, it was a land of "excess, where the elements are never moderate or in humour," and this inefficiency bespoke its otherworldliness: "there was something almost Biblical in the way the deities of this ancient land conspired to punish us ... heat and drought; hunger and thirst and flies; damp and cold, fever and ague, flood, hurricane and rain." Technology could only improve a land so far from England, so close to an unforgiving God. ${ }^{64}$

63. Albert Hourani, "The Myth of T. E. Lawrence," in Adventures with Britannia: Personalities, Politics and Culture in Britain, ed. William Roger Louis (London: I. B. Tauris, 1995), 9-24, here p. 23; Lawrence, The Seven Pillars of Wisdom, 327.

64. G. M. Chesney, "Mesopotamian Breakdown," Fortnightly Review 102, 1917, 247-56, here p. 247; Swayne, In Mesopotamia, 17 and 51; Candler, The Long Road to Baghdad, 1:33 and 176; Mesopotamia Commission Report, 9; Nunn, Tigris Gunboats, 10; Candler, The Long Road to Baghdad, 1:1, 50, 72, 99, and 164; "A Truce in the Desert: Turks' Arab Allies," Times, March 22, 1916, 7. 
After Kut, "the conditions of France were repeated in Mesopotamia," Candler noted ominously. But rather than lament, as did Britons in France, that technology paralyzed military activity, critics deplored the Mesopotamia force's lack of access to modern technology - the wire-cutters, water-carts, Véry lights, rockets, mosquito nets, periscopes, and medical facilities essential to "war carried on under modern conditions." The campaign's initial mobility had frustrated "the business of rangefinding and registering, so easy in the stationary conditions on the western front"however fruitless those abilities had proved in that context. The Mesopotamia Commission bemoaned "the discredit ... to the Indian Military Authority that such a modern device [as Véry lights] ... should have been in use by the Turks ... before it was supplied to our own troops." In France, noted Candler, the wounded were whisked away in "smooth motor ambulance wagons" and provided with "every saving device that Science can lend," while in Mesopotamia "all was chaos." Imperial prestige was at stake; Indian soldiers saw that in France, "the Sirkar had never failed." Modern warfare had come to mean the mobile supply of an immobilized army in a clearly demarcated battlefield. ${ }^{65}$

But this period of trench warfare was followed by a magnificent rush to Mosul, which seemed to be a rite of passage to an ultra-modern warfare that vindicated western front tactics. The resumption of a breathless pace after the War Office and a chastened Indian military establishment began to provision everything from aircraft to harbors proved that there was life after trench warfare, that stalemate could end. "Bloody, remorseless trench fighting," Candler attested, "was a thing of the past." Armed with all the paraphernalia of modern warfare, they waged "war as it should be waged, with the spirit of movement in it, the new scenes a background to the drama of battle ... waiting to be explored." Defying the wisdom from France that "modern warfare" had rendered long advances impossible without "a certain calculated sacrifice which is generally prohibitive," in the Middle East the British were both modern and highly mobile. It was the conditions in France that now appeared "abnormal." These campaigns seemed to prove the reigning military science sound; the cavalry was "saved ... from utter extinction." ${ }^{66}$ Indeed, this was partly the reason why, as General Charles Townsend observed, the military establishment remained committed to the "cult of the offensive":

The Napoleonic war of manoeuvre or movement was rendered practically impossible, after the Battle of the Marne, and ... a war of entrenchments, more suited to a secondary theatre, became the order of the day.... On the other hand, the operations in the secondary theatres of the war, such as Palestine and Mesopotamia, were wars of manoeuvre and movement. ${ }^{67}$

In 1917, the Times declared "no example of the war of movement ... better worth study" than "Mesopotamia To-Day." At Ctesiphon, a naval officer mused on the

65. Candler, The Long Road to Baghdad, 1:50, 72, 99, 164, 47, 56, and 102; Mesopotamia Commission Report, 37-38.

66. Candler, The Long Road to Baghdad, 1:1, 47, 51, 132,111-20, 164, and 2:223-24; Gilbert, The Romance of the Last Crusade, 222.

67. Charles Vere Ferrers Townshend, My Campaign in Mesopotamia, 2 vols. (New York: J. A. McCann, 1920), 1:1-36, here p. 19. 
historic figures that "had passed this way before the coming of men in khaki, with their aeroplanes and wireless." The ubiquitous aircraft heralded a futuristic warfare in which chivalry and individual exploits still had a place, as did the ad hoc innovations of the campaign. One officer insisted that the troops never felt cast in a sideshow because the presence of fewer battalions made each feel more important. "You couldn't have a more interesting show," he assured his mother, what with the cavalry, armored cars, pontooning — "all these fancy corps alongside us." Where the work of the occupying forces was carried out by individuals and aircraft, heroism stood out in sharp relief against the backdrop of anonymous mass slaughter on the western front. Military journals after the war noted the "perfectly reasonable reversal in the importance of the various campaigns": while France and Belgium had preoccupied military theorists during wartime, the so-called "sideshows," especially Mesopotamia and Palestine, had since seized attention for their demonstration that new technologies guaranteed all future warfare would be "small" and that, as at Waterloo, "mobility and power" could still be "rightly correlated." In postwar Iraq, the RAF assembled social and educational programs and tours of the battlefields, fueling the growing awareness that "the Mesopotamian operations, subsidiary though they were at the time, have a special value in the study of military science." 68

Today we have lost this sense of how the Middle Eastern campaigns mattered culturally and militarily. At the time, however, frantic efforts were made to educate the British public about the campaigns' achievements following their new success. Works on Arabia written to official order impressed readers with the Mesopotamia campaign's worthiness and glamour. For instance, Gertrude Bell composed press release articles for the War Office and anonymously authored The Arab of Mesopotamia, a collection of essays popular among troops as well as literary circles at home. Her office issued soldiers with handbooks emphasizing Mesopotamia's ancient role as the "main avenue for riches and the wealth of the East" and assuring them that their "sideshow" was what stood between India and the war. These texts made sure soldiers knew that their "little show in Mesopotamia ha[d] done as much to save the Empire as any other." ${ }^{69}$ The state propagated the hope that redemption would be found in the Middle East in order to strengthen morale and win public opinion over to the idea of empire in the region. The fall of Baghdad inspired wonder and hope because it was "Baghdad!" a place "famous for the men and armies that had crossed it." The capture of "Dar-as-Salam, the

68. "Mesopotamia To-Day," Times, July 11, 1917, 7; Nunn, Tigris Gunboats, 168; LULLC, GS 1162, Joseph Napier to the Department of War Studies, Sandhurst, 1976, and to his mother, February 28, 1917; "Dalil," "The Campaign in Mesopotamia: The First Phase," JRUSI 69/475 (1924): 510-26, here pp. 510-11; H. Rowan Robinson, "The Relations of Mobility and Power," JRUSI 65/459 (1920): 572-79, here p. 579; "Battlefields of Iraq," Times, December 12, 1923, 11; "Battlefields of Iraq II," Times, January 18, 1924, 11.

69. Gertrude L. Bell to Florence Bell, September 5, 1918, in The Letters of Gertrude Bell, ed. Florence Bell (London: Benn, 1927), 2:461-62; IOR, CPO, IEF “D," in John Malcolm, Sketch of the Political History of India from 1784 to the Present Date (London: Miller, 1811), chap. 1; Tab, On the Road to Kut, 111; Satia, Spies in Arabia, chap. 9. 
City of Security" instilled "confidence." It was hailed as "the most triumphant piece of strategy ... since war started" and "the first big place we've taken in this war." Candler reeled off the past rulers of Baghdad-Nebuchadnezzar, Alexander, Cyrus, Julian, Haroun al-Rashid_- "and now it was General Maude." He had become "one of the immortals," and his death from cholera late in 1917 was compared to those of the emperors Julian and Alexander. ${ }^{70}$

Baghdad's appeal convinced the pious and shrewd Lloyd George to make Jerusalem a "Christmas gift" to the British people_-just when the Passchendaele offensive ended in costly failure. References to the Crusades were designed to resonate with the deepest beliefs of a long-suffering nation, and the fall of Jerusalem incited unprecedented public euphoria-the Bell of Westminster chimed for the first time in three years. The War Office sent over Harry Pirie-Gordon to write popular articles, and, at the behest of the US ambassador Cecil Spring-Rice and John Buchan, director of the Department of Information, Lowell Thomas landed up at Lawrence's tent in search of that rare thing, a Great War hero to rouse the militarism of the United States. The influential Middle East policy-maker Mark Sykes urged Cairo intelligence to dispatch "popular" and "picturesque" reading for the average church-going Briton and "rivet the British onto the Holy Land." In the Observer he described Jerusalem as a "new Light of the World" that would renew Christendom, bidding his audience to "take up their lives again with hope reawakened and faith renewed." He spent hours editing propaganda for Buchan before launching a department for Middle East propaganda in the Foreign Office. He went on lecture tours spreading anti-Turkish doctrine and giving currency to the term "Middle East," and his dramatic maps of Germany's "Drang Nach Osten" could be found all over Fleet Street. ${ }^{71}$

The Middle East campaigns thus seemed to redeem warfare itself as a productive enterprise. If technology's dark side was exposed in France, in the hands of "experts" in Mesopotamia it resurrected both a military campaign and a devastated civilization. Restoring Mesopotamia was "the talk of the dinner-table" among the ranks. The object of the campaign was now a "regenerated Babylonia, in which the ancient streams reflect once more mighty structures of men and gardens like Paradise, and in the streets of whose cities traffickers from all the earth once more meet." The oft-repeated list of materials provided by India-timber, steel, dredgers, electrical plants, cable, engines, labor to build ships, wharves, railroads, dams, canals, harbors, and telegraphs-was a proud inventory of British imperial beneficence. Lord Montagu, the new secretary of state for India, and Robert Cecil, parliamentary undersecretary of state for Foreign Affairs, acclaimed the Indian Mesopotamia force in Parliament for "changing the appearance of the country and

70. Clark, To Bagdad with the British, 208; Wauchope, With a Highland Regiment in Mesopotamia, 65; Clark, To Bagdad with the British, 239; Candler, The Long Road to Baghdad, 2:97.

71. LULLC, AIR 032, Robert Blucke to his father, June 25, 1917; Telegram from Sykes to Clayton, January 16, 1918, quoted in Wilson, Lawrence of Arabia, 466-67; Sykes in the Observer, December 1917, quoted in Roger Adelson, Mark Sykes: Portrait of an Amateur (London: Jonathan Cape, 1975), 246. 
eradicating the blight of Turkish misrule." 72 That imperial forces were the agents of this work redeemed the war from purposelessness. As Wauchope explained in Blackwood's Magazine:

Watching these columns of Englishmen and Highlanders, of Hindus, Gurkhas and bearded Sikhs advancing [within sight of Babylon's Median Wall], one felt the conviction that this struggle was being fought for the sake of principles more lofty, for ends more permanent, for aims less fugitive, for issues of higher service to the cause of humanity, than those that had animated the innumerable and bloody conflicts of the past. ${ }^{73}$

The development of Iraq served not only the military need to produce battlefields and nature itself out of a disordered landscape, but also the cultural need for proof of Britain's constructive powers.

This process was framed as the restoration of the country's ancient order. The dams and canals ravaged by the Mongols, on which "some fifty centuries of prosperous civilisation had been based," would be restored, proclaimed the Times after the war, and Clio would return as Baghdad's mystery was "violated by the whirring wheels ... of trains, of cars, of aeroplanes." Aircraft recalled the sorcerers who had made Sinbad the Sailor turn airman on the back of a great bird, while motorcars were "snorting land monsters which rush across the deserts"—- The age of miracles has happily returned, and we may see strange Arabian nights in the coming years." 'The press seized on the notion of Baghdad as the "Clapham Junction of the air," the site of the "natural junctions" of the world's airways and railways. In its future as in its past, Iraq's destiny was to be “the world's centre." Developing Mesopotamia was simply a matter of refitting it, through modern technology, to resume its traditional role in a peaceful postwar world. As David Edgerton notes, it was liberal Britain rather than the Fascist regimes that pioneered air warfare, and it did so by couching airpower as a force for peace and trade anchored in the world's oldest commercial center. ${ }^{74}$

72. Egan, The War in the Cradle of the World, 252; Edwyn Bevan, The Land of the Two Rivers (London: E. Arnold, 1918), 10-11, 112, and 124-26; Robert Cecil, House of Commons debate, July 23, 1918, quoted in Arnold T. Wilson, Mesopotamia, 1917-1920: A Clash of Loyalties. A Personal and Historical Record (London: Milford, 1931), 99; Montagu, House of Commons debate, August 6, 1918, reported in the Times, August 7, 1918, 8.

73. Wauchope, "The Battle that Won Samarrah," reprinted as chap. 8 of With a Highland Regiment in Mesopotamia, citation p. 85.

74. "Four Centuries of History," review of Stephen Hemsley Longrigg, Four Centuries of Modern Iraq (Oxford: Oxford University Press, 1925), Times, January 22, 1926, 17; "A Traveller in Mesopotamia," review of E. S. [Ethel Stefana] Stevens, By Tigris and Euphrates (London: Hurst and Blackett, 1923), Times, December 14, 1923, 8; "Britain and Mesopotamia," Daily Telegraph, May 10, 1921; R. J. Wilkinson, "The Geographical Importance of Iraq," JRUSI 67/468 (1922): 660-65, here p. 663; David Edgerton, Warfare State: Britain, 1920-1970 (Cambridge: Cambridge University Press, 2006), 284, 312, and 317. In India, by contrast, the signs of wartime modernization were most often viewed as a violation of the colony's romantic aura, betokening social, cultural, and political chaos. 
The Mesopotamia campaign came to be seen less as a "sideshow" than the place where the war could find meaning; less an oriental escape from industrialism than the proving ground for British industry and empire. By "reclaim[ing] a wilderness," and "rebuild[ing] a civilization after many years of anarchy and desolation" for "a new country and a new people," the British force would give meaning to the sacrifices of British soldiers. ${ }^{75}$ In a terrain hallowed by its "mysterious and divine" $" 76$ origins and by their soldiers' sacrifice, Britons articulated an imperial identity that could explain away the missteps that had landed them in the Great War. A sailor wrote in a 1917 memoir:

We Britons spend our lives in making blunders, and give our lives to retrieve them. But though the clouds remain, they are no longer dark and threatening; the dawn has come, and with it the confident assurance that in this new burden of Empire-the task of restoring Mesopotamia to her former prosperity — the generations to come will gain inspiration from the long chronicle of heroic deeds which make up the story of her deliverance. The lives of Britain's sons have not been sacrificed in vain. ${ }^{77}$

This was a restoration of East as much as West. Far from "unchanging," this region of the East had metamorphosed from a locus of power and riches, closely bound to Hellenistic-Christian culture, into a "sordid relic." "When European Christendom looks to-day at the desolation of these lands," wrote the historian and philosopher Edwyn Bevan, "it is looking at a lost piece of itself." Restoring Arabia was part of the larger project of restoring the Old World after its orgy of self-destruction: in its development lay the hope of a better life for "western peoples." ${ }^{\prime 7}$ As in the past, at this epochal juncture, Mesopotamia held "the key to the whole world's future." In an essay much circulated amongst the troops, Bell evoked a vision of revived ancient markets adding "immeasurably to the wealth of a universe wasted by war" and providing new fields for European industry. "Nowhere, in the war-shattered universe," she held, "can we begin more speedily to make good the immense losses sustained by humanity." She effused about the government's strides in "the making of a new world." While those at home were "over-strained," "we are out of that atmosphere here." Candler was comforted "that the war which had let loose destruction in Europe was bringing new life to Mesopotamia," a sentiment echoed in the Guardian. Global salvation would also be the salvation of empire. ${ }^{79}$ As one officer confided to another:

75. Reynardson, Mesopotamia, 272.

76. Barker, The Bastard War, 42.

77. Cato, The Navy in Mesopotamia, 106 and 117.

78. Bevan, The Land of the Two Rivers, 10-11, 112, and 124-26.

79. Joseph T. Parfit, Mesopotamia: The Key to the Future (London: Hodder and Stoughton, 1917), 1; Gertrude Lowthian Bell, "Turkish Province: The Anatolian Coast," and "Arab Provinces: Baghdad," in The Arab of Mesopotamia (Basra: Government Press, 1916), respectively 119-32 and 201-2, citations pp. 131 and 201-2; Bell to Hugh Bell, May 18, 1917, and to Florence Bell, November 15, 1917, in Letters of Gertrude Bell, 2:410-11 and 431-32; Candler, The Long Road to Baghdad, 2:183; "A New Mesopotamia," Guardian, December 13, 1919, 12. 
All this show of ours out here is nothing in itself. ... It's a beginning of something that will materialise a hundred or two hundred or a thousand years hence. We are the great irrigating nation and that's why we're here now. ... We'll fix this land up ... and move the wheels of a new humanity. Pray God, yes—a new humanity! One that doesn't stuff itself silly with whisky and beef and beer and die of apoplexy and high explosives. ${ }^{80}$

Mesopotamia proved that the British could still civilize, even if they had lost civilization itself. The "great enterprise of the regeneration of Palestine" was likewise "one of the few fine and imaginative products of the war," vouched the Guardian. The knowledge that the final crusade had brought "peace and freedom" to the Holy Land after five hundred years made "it all [seem] worth while." In 1926, the colonial secretary Leo Amery still spoke of the "great development in Iraq which will bring us some recompense for the great sacrifices we made in the Great War."

The Middle East made idealism possible even as the western front stoked cynicism and irony. If the war was "mindless" elsewhere, in the Arabian desert, "the reservoir of all ideas," new ideals were found. General Reginald Wingate hoped that "in ... Arabian union," with Britain as "Patron \& Protector," "may lie not merely a ... solution of ... our present difficulties but possibly the foundation of a really constructive scheme for the future." ${ }^{82}$ By making man once again "master of the great waters" of Mesopotamia, wrote Bevan, the British would end the destruction wrought by tyrants since the Mongol invasion. They would resurrect the imperial tradition of improvement, taking up the mantle of the Persians, Seleucids, Parthians, Sassanides, and the Saracen caliphs. They had launched a "programme of public works as has no parallel in that ancient land since ... ALEXANDER THE GREAT," proclaimed the Guardian. Far from ideologically bankrupt, the empire had finally arrived. "British seed" would make the desert "bloom as the rose," promised an officer, answering those who called empire "a thing of pitiless blood and iron." ${ }^{83}$ And this also distinguished the British from the rest of Europe. "It was interesting," said Montagu in Parliament, "to compare British occupation in Mesopotamia with German occupation in Belgium"-a remark that was met with cries of "Hear, hear." The point was not "painting Mesopotamia red," assured the arch-imperialist George Curzon, but "redeeming the country from anarchy." If Arabs appeared ungrateful for their deliverance, what better proof of Britons' selflessness? As in Egypt and Punjab, explained Sykes, the British imperial ideal was "not ... conquest but ... redemption."

80. Quoted in Swayne, In Mesopotamia, 166.

81. "The Palestine Mandate," Guardian, June 23, 1922, 6; LULLC, GS 1429, Sir Reginald Savory, "Recollections," undated TS; Amery at the Leeds Luncheon Club, quoted in the Times, February 9, 1926, 11.

82. Thomas Edward Lawrence, “The Changing East," in Oriental Assembly, 87; TNA, FO 882/XIV, MIS/15/9, note by Wingate, August 26, 1915. 
"Truly we are a remarkable people," Bell mused. "We save from destruction remnants of oppressed nations, laboriously and expensively giving them sanitary accommodation, teaching their children, respecting their faiths," yet continue to be cursed by these subjects, who, nevertheless, "when left to themselves ... flock to our standards. ... It's the sort of thing that happens under the British flag-don't ask us why." Surveying the "reviving world," she felt "part of Mesopotamia and not part of an army of occupation." Throughout the 1920s, Iraqi intransigence was deemed an "inscrutable visitation of divine wrath upon a nation that presumed to aid a fallen land to rise phoenix-like from the dead ashes of its past." 84

Domestic criticism of Middle East policy was deflated by the press's enthusiasm for resurrecting Babylonia and its "benefit to the world." Even if Britain profited from Mesopotamia's future "untold wealth," it would not be for "motives of 'land-grabbing' and Imperialism in its worst aspects," but minor recompense for the country's "rescuers." That India was the agent of Mesopotamia's recovery proved that Indians knew Britain ruled for their good and "not to exploit India for the benefit of this country," exclaimed a parliamentary paper. John Stuart Mill's version of empire had been vindicated, announced the Times: Britain's was a "steadfastly progressive rule ... the most beneficent in design and execution known in the history of mankind." Through Mesopotamia, British beneficence toward India had been "blessed not only to the giver and the receiver, but to the world at large." Through the early 1930s, officials held that "in the welter of world politics and imperial problems the establishment of the new State of Iraq ... 'shines like a good deed in a naughty world." It showed the world that the empire was not for "imperial domination or material rewards," but for the good of others. ${ }^{85}$ The Middle East campaigns were central to the interwar shift in imperial propaganda from militarism to more idealistic economic themes that preserved the empire's respectability, presenting it as an "interlocking economic unit" that collectively guaranteed mutual advancement. ${ }^{86}$ So warmly did the light of hope glow in postwar Iraq that soldiers at a loose end sought transfer there. Weary from four years in France and Belgium, the legendary career of John Glubb, who would train and

84. Lord Montagu, speech in a House of Commons debate on Indian reform, August 6, 1918, reported in the Times, August 7, 1918, 8; Curzon at the Central Asian Society, reported in the Spectator, October 16, 1920, 487; MECA, Sykes Papers, box 2, file 7, document 78, "Political Note on Our Advance in Irak," September 17, 1917; Gertrude Bell to Hugh Bell, November 10, 1922, and to Hugh and Florence Bell, January 31, 1918, in Letters of Gertrude Bell, 2:657 and 441-44; Candler, The Long Road to Baghdad, 2:188. 85. "Lest We Forget," Times of Mesopotamia, May 3, 1924; "The League of Nations and Mosul," Spectator, September 12, 1925, 398; Economist, May 10, 1924, 955; LULLC, GS 0089, Barnett to his mother, October 6, 1916; Cabinet Paper on Mesopotamia, November 12, 1919; East India (Military), Cd. 7624, Parliamentary Papers, 1914-1916, 49:15; Times Trade Supplement, December 2, 1918, 206b; Sir Nigel Davidson, "Iraq: The New State," Journal of the Royal Central Asian Society (hereafter "JCAS") 19, no. 2 (1932): 212-33, here pp. 212-16.

86. On the notion of empire as an interlocking economic unit, see John M. MacKenzie, Propaganda and Empire: The Manipulation of British Public Opinion, 1880-1960 (Manchester: Manchester University Press, 1984), 10-11 and 107. 
command Transjordan's Arab Legion, was launched when he read, "with something of a throb of excitement," of the need for volunteers in Iraq-the prospect of more fighting "and all the excitement and interest of adventure and a strange country." James Mann, a political officer in Iraq, likewise reasoned with his mother: "If one takes the Civil Service, or the Bar, or Literature, or Politics, or even the Labour movement, what can one do that is constructive? Here on the other hand I am constructing the whole time." ${ }^{87}$

They were inspired partly by veterans from the campaigns who were catapulted to fame and high official positions. Arnold Wilson, the former civil commissioner in Baghdad, observed proudly that "the governments of all the British territories on the coast of East Africa" were by 1932 "in the hands of men who won their spurs either in Mesopotamia or ... Palestine." If imperial and chivalric values survived the war, it was largely thanks to the legend depicting these agents as redeemers from the desert, embodying the hope that the past might survive and the future hold greater promise. The romance of the campaigns, the modernist imagery of the RAF-ruled postwar Middle East, and the Faustian charge of remaking the cradle of civilization were central to this legend. If Lawrence's political capital lay in his status as an "expert" in the development of the region on which postwar society had staked redemption, his cultural capital lay in a discourse about the ultimate redeemer from the desert, which built on the image of the imperial adventure-hero while envisioning a new kind of modernist prophet. His role in the Arab revolt was hailed as "a spiritual even more than a physical exploit." He was "utterly divided from his contemporaries" by superior spirit and a "puckish quality." 88

Lawrence emerged the only unanimously adored action-hero of the war. The need for a hero aside, postwar British society possessed the means of generating a mythic hero of gigantic proportions thanks to the new dramatizing media and the rapid growth of mass-circulation dailies. He became "the first media legend," 89 and Lowell Thomas's lecture-slideshow about him broke show business records. Millions saw it in 1919, including the royal family and the Cabinet. It moved from Covent Garden to the Albert Hall and toured internationally. Lawrence's popularity guaranteed him the press space to substantiate it with his own journalism, and his serial narrative of the Arab revolt appeared in the Strand Magazine in 1920 as

87. John Glubb, The Story of the Arab Legion (London: Hodder and Stoughton, 1948), 19; Mann to his mother, January 25, 1920, in Mann, An Administrator in the Making, 206. See also the file of applications, many from war veterans, for appointment to the Mesopotamian Civil Administration, especially as political officers: IOR, L/PS/10/676, 1918-21. For the Conservative Party, opportunities for constructive work in the field of imperial development helped strengthen the commitment of the nation's youth to the empire-and to the party. See, for instance, Leo Amery's speech in the City Hall, Glasgow, at a meeting of the Junior Imperialist Union on January 21, 1926, reported in "Youth and Empire," Times, January 22, 1926, 7.

88. Arnold T. Wilson, “Annual Dinner," JCAS 19, no. 4 (1932): 643-52, here p. 644; Arnold W. Lawrence, ed., T. E. Lawrence, by His Friends (1937; repr. London: Jonathan Cape, 1954), 128; Stirling, Safety Last, 83-84. 
"The Uncrowned King of Arabia." The Thomas show and the exhibition of Eric Kennington's portraits for The Seven Pillars of Wisdom at the Leicester Gallery in London merged with a postwar genre of films portraying the Palestine war with a "boys' adventure stories" approach. Boys' papers idolized Lawrence as the "Silent Sentinel of the Sand," and the "Man Who Won a War on His Own." Desert battle emerged as a major cinematographic theme, depicting a region preserving values lost to the West-austere, chivalrous, virile, individual, timeless. Cinematographic expeditions to Iraq were common, too. A genre of "sheikh" films-launched in 1921 with Rudolph Valentino in The Sheikh-romanticized the desert and Arab virility. The Sheikh was based on a 1919 novel by Edith Hull, the most successful among a "myriad of desert-passion novels." Its sales surpassed "all the contemporary bestsellers lumped together," with 108 editions appearing between 1919 and 1923 in Britain alone. Graves thought it a "cosmic joke" that booksellers had to explain that Revolt in the Desert, Lawrence's 1927 abridgment of Seven Pillars, was not a sequel to Son of the Sheik. Despite-or perhaps because of-the confusion, "no book within memory has been greeted ... with such frank enthusiasm by every sort and condition of reader," remarked Cox. It generated a subgenre of works on "war in the desert," spawning histories, captivity narratives, and military memoirsnon-fictional genres that exploited the scenic structure of the Middle East campaigns. If, as Fussell has told us, conscripted soldiers in France drew on the theatrical idiom to explain their wartime roles, the Middle Eastern theater felt less ironically stage-like, offering a structure and meaning that were readily transformable into entertaining narratives. Many veterans of the campaigns shared Lawrence's publishing success. ${ }^{90}$ The region became the cynosure of scholarly societies, particularly the Central Asian Society, where there was "great rejoicing ... over the influx of new members from Mespot" as membership swelled from 132 in 1918 to 1,082 in 1928. By 1925, the imprecision of the term "Central Asia" had become a running joke. Bertram Thomas's lecture on his crossing of the Rub alKhali was so popular that "it was impossible for all to get into the lecture-hall." At the Royal Geographical Society, too, experts expounded on the constructive results of the war in the Middle East and the civilizational promise of air control. ${ }^{91}$

90. Dawson, Soldier Heroes, 167-83; MacKenzie, Propaganda and Empire, chap. 3; Paris, Warrior Nation, 151 and 171; IOR, Eur. MSS, C874, Ilay Ferrier, "The Trans-Desert Route," TS, 1926; Billie Melman, Women and the Popular Imagination in the Twenties: Flappers and Nymphs (Basingstoke: Macmillan, 1988), 91; Virginia Woolf, Night and Day (New York: Harcourt Brace Jovanovich, 1948), 83; Graves, Lawrence and the Arabs, 57; Percy Cox, review of Lawrence, Revolt in the Desert (London: Jonathan Cape, 1927), Geographical Journal 69, no. 6 (1927): 581-82; Fussell, The Great War and Modern Memory, chap. 6; Satia, Spies in Arabia, 184. On films inspired by Arabia, see Sari J. Nasir, The Arabs and the English (London: Longman, 1976), 125-48.

91. British Library, London, Wilson Papers, 52456A, Stephenson to Wilson, May 26, 1920; Bertram Thomas, "Across the Rub 'Al Khali," JCAS 18, no. 4 (1931): 489-504, here p. 489; Harry St John Philby, "A Survey of Wahhabi Arabia, 1929," JCAS 16, no. 4 (1929): 468-81, here p. 468; "List of Members of the CAS," JCAS 15, no. 1 (1928): 3-39; Satia, Spies in Arabia, 184. 
Although one might never guess it from standard histories of the war's cultural impact, the mania for Arabia permeated popular culture, from fashion and décor to music and tourism, unleashing a torrent of imitative tourist tales. Bell inspired a train of visitors to Baghdad, especially those she described as "silly females, all with introductions to me." Many traveled by the light of Revolt in the Desert-literally "in the steps of Lawrence," as one title proclaimed. Major Jarvis of Palestine fame sneered at the countless copycats looking for "thrilling adventures among Lawrence's Arabs." A good number of these texts included novelistic descriptions of first meetings with Lawrence, a bedraggled, prophet-like character, as instantly recognizable as the hero of any popular adventure series. Encounters with Lawrence were ubiquitous in the fiction of Buchan, George Bernard Shaw, W. H. Auden, Henry Williamson, D. H. Lawrence, Cecil Day Lewis, and W. B. Yeats. This fascination had as much to do with Lawrence's role in Arabia as his role in the RAF, which he joined in 1922 under the name of T. E. Shaw, in homage to one of his greatest literary patrons. "Lawrence" sold. The name's career became entwined with postwar publishing. Works by E. M. Forster, Frederic Manning, and others were dedicated to him partly for the cash value of his name, as was Graves's 1929 poem "The Clipped Stater." Indeed, so wide a swath did Lawrence cut through literary society that Graves mocked those mimicking his gestures and speech. Graves's own career was particularly influenced by Lawrence, who had served alongside his brother Philip Graves in Cairo and was already familiar with his poetry when they met after a dinner at All Souls' College, Oxford. Lawrence submitted chapters of Seven Pillars to support the literary magazine of his indigent new friend, and allowed Graves to write a popular account of him for the publisher Jonathan Cape, thereby establishing him financially. ${ }^{92}$ In GoodBye to All That (1929), Graves warmly acknowledged his financial and literary debts to Lawrence, including his appointment as a teacher in Cairo. He included these acknowledgments in a book written to make "a lump of money," partly because people "like hearing about T. E. Lawrence." Lawrence also gave Graves critical feedback on I, Claudius (1933), for which he was thanked in the preface. Graves and Laura Riding's pseudonymously published No Decency Left (1932) incorporated an "autogyro of the future" designed by Lawrence. Graves's neighbor in Oxford was the imperial critic and (after 1923, ex-) Methodist minister Edward Thompson, who after a stint in India had ministered to the troops in the Middle East and emerged a prolific chronicler of those campaigns (his views on empire substantively influenced his son, the historian E. P. Thompson). ${ }^{93}$ Lawrence was moreover "one

92. Gertrude Bell to Hugh Bell, March 11, 1925, in The Letters of Gertrude Bell, 2:725; review of Paul W. Harrison, The Arab at Home (New York: Thomas Y. Crowell, 1924), in JCAS 13, no. 3 (1926), 279; Douglas Glen, In the Steps of Lawrence of Arabia (London: Rich \& Cowan, 1939); Jarvis, Arab Command, 141-42; Wilson, Lawrence of Arabia, 675; Satia, Spies in Arabia, 185-90.

93. Graves, quoted in Fussell, The Great War and Modern Memory, 205; Lawrence to Graves, April 21, 1931, and Brown's note on this subject, both in Lawrence, Selected Letters, 452-453; Satia, Spies in Arabia, 187-90. 
of the most significant private patrons of contemporary artists in Britain," involving Kennington, Augustus John, William Roberts, Frank Dobson, Wyndham Lewis, and Paul Nash in the production of Seven Pillars. ${ }^{94}$ All this puts Lawrence and the Middle East backdrop of his fame squarely in the mainstream of twentieth-century British intellectual and cultural history. That Lawrence shaped a figure as central to our understanding of the western front as Graves, renders more dubious the notion that that front's cultural significance was unique and self-contained. When we talk about Graves and Siegfried Sassoon and the western front, we are getting only part of the picture.

Seven Pillars was written within and for this intellectual and artistic community; hence the limited subscribers' edition that made it the "the decade's most talked about and least available book." It was among those books trying to come to terms with the war, and if our scholarship has held it apart from that canon, contemporaries had no doubts as to its relevance. Literary savants from Churchill to Forster considered it a masterpiece, H. G. Wells ranking it with Robinson Crusoe and The Pilgrim's Progress. Buchan called Lawrence the best prose writer of his day and owned he would have followed him "over the edge of the world." 95 David Garnett considered Seven Pillars "the only big book to come out of the war; the only thing to which my generation can point with certainty," even though it was "a freak in literature, a freak by virtue of its subject $\&$ the character of its author, \& the nature of his achievement." Sassoon was grateful "that a great war-narrative (\& criticism) has been written by one who is the same sort of human being as SS [his initials]." 96 Lawrence was visited by nightmares, which he recognized as a symptom of the inability to "get away from the war" that he shared with Graves and Sassoon. He too was hooked on "war books." 97 If the Lawrence legend provided reassurance of continuity with the past, his artistic investment was in depicting the disillusionment that gripped his peers; in a sense, as an individual drawn to Arabia by a precocious disenchantment with European civilization, he had anticipated them. While Seven Pillars was full of heroic action otherwise absent from the memory of the war, it also told the story of a hero's bitter disillusionment with his country's duplicitythe tragic element that makes the book unmistakably modern whatever its romance. Lawrence expressed postwar disillusionment, the "generation gap" if not the direct experience of the generation tied to the western front. ${ }^{98}$ In All Our Yesterdays (1930),

94. Charles Grosvenor, “The Subscribers' Seven Pillars of Wisdom: The Visual Aspect," in The T. E. Lawrence Puzzle, ed. Stephen E. Tabachnick (Athens: University of Georgia Press, 1984), 159-84; Satia, Spies in Arabia, 185-88.

95. Desmond Stewart, T. E. Lawrence (London: Paladin Grafton, 1979), 233, quoted in Dawson, Soldier Heroes, 205; Buchan to Lawrence, July 13, 1927, in Arnold Walter Lawrence, ed., Letters to T. E. Lawrence (London: Jonathan Cape, 1962), 20-21; John Buchan, Memory Hold-the-Door (Toronto: Musson, 1940), 218; Satia, Spies in Arabia, $188-89$.

96. Garnett to Lawrence, Guy Fawkes Day (November 5), 1927, and Sassoon to Lawrence, December 6, 1923, both in Letters to T. E. Lawrence, 76-78 and 155.

97. Lawrence to Graves, quoted in Wilson, Lawrence of Arabia, 668.

98. Satia, Spies in Arabia, 188-89. 
H. M. Tomlinson strove to portray the sort of thing he felt had happened to Lawrence: "The evil that others had done caught you, \& you faced it for them[and were] crucified." "There you are," he wrote of Lawrence's The Mint, "with the ruthless mind of this younger generation, regarding the wreckage of a world ruined by the last of the Victorians ... and some scruple keeps you from sorting it out for us, as you could all right." It was a book "young men" would instantly recognize and "the old in mind \& obsolete" rail against. He beseeched its author, then stationed in India, to "Come over \& help us!" While symbolizing the continued validity of traditional notions of heroism, Lawrence's legend was also identified with forces of change and distanced from discredited elements of the old order. ${ }^{99}$ Contemporaries found in him "evidence that a literary, modern heroism was possible," even if Lawrence had no personal faith in his deeds or in heroic action per se. Liddell Hart closed his biography on a crescendo: "The young men are talking, the young poets writing, of him in a Messianic strain-as the man who could, if he would, be a light to lead stumbling humanity out of its troubles. ... He is the Spirit of Freedom come incarnate to a world in fetters." This admiration was inseparable from a fascination with the Arabian backdrop of his fame: he was, after all, Lawrence "of Arabia." His native qualities, the architect Herbert Baker explained, had "deepened and matured in the solitude of the Arabian desert, ever the breeding place of saint and prophet." In a sermon on Lawrence's death, the Reverend Leslie Basil Cross compared him to Christ, and Lawrence's own self-deprecating comparisons to the Savior in Seven Pillars only strengthened the allusion. ${ }^{100}$

Lawrence was not alone among Middle East veterans in being embraced by the literati. Bell appears in works by Vita Sackville-West and Virginia Woolf. George Lloyd, St John Philby, and Aubrey Herbert were also entangled in this world, as was Leonard Woolley, via Agatha Christie and Rudyard Kipling. Through them, many literati met others from the Middle East theaters who, if not as consistently as Lawrence, were sometimes also held up as prophet-like heroes. ${ }^{101}$ Perhaps unsurprisingly, these super-heroic individuals were admired by FascistsLawrence was on his way to discuss politics with Henry Williamson when he met with his fatal accident. But Socialists admired them too: counting Lawrence among those who "want to make this present world feel the fool it is," Wells promised him a copy of The Open Conspiracy (1928), setting forth his program for a global movement of visionaries who would lead humankind out of the moment of crisis into a utopic, scientifically managed cosmopolis. All those dissatisfied with the

99. Henry Major Tomlinson to Lawrence, March 19, 1930, and December 5, 1928, in Letters to T. E. Lawrence, 189-93; Dawson, Soldier Heroes, 176.

100. Hynes, The Soldier's Tale, 92; Eugene Goodheart, "A Contest of Motives: T. E. Lawrence in Seven Pillars of Wisdom," in T. E. Lawrence: Soldier, Writer, Legend: New Essays, ed. Jeffrey Meyers (Basingstoke: Macmillan, 1989), 122; Liddell Hart, "T. E. Lawrence," 447; A. W. Lawrence, T. E. Lawrence, by His Friends, 149 (Liddell Hart) and 205 (Baker); Satia, Spies in Arabia, 193.

101. Ibid., 189-94. 
present saw hope in certain "personalities," and the heroes who had apparently exercised such a profound influence over Arabia by sheer "force of personality" possessed a particular appeal. ${ }^{102}$

The association with Arabia mattered not for its exoticism but for the particular vision of Englishness it expressed. On the one hand, Lawrence was inscrutably oriental: "When one is tempted to accuse him of being unreasonable," wrote Liddell Hart, "the echo of his own comment on the Arabs comes as answer'Their minds work just as ours do, but on different premises." Buchan defied anyone to understand him: there was no brush fine enough to capture the subtleties of his mind, "no aerial viewpoint high enough to bring into one picture the manifold of his character." At the same time, these commentators, and Lawrence himself, insisted on his Englishness, assimilating love for the desert as a peculiarly English trait: the desert's native inhabitants "lived in heaps," he remarked, but it was "a part of pride with Englishmen to hug solitude." His fellow veteran Lord Winterton likewise held that life could only be enjoyed "in the desert and in this country." Arabs and the English shared the "gift of personality," and the British fascination with Bedouin chivalry was part of an effort to recuperate their own. "We find, in the bedouin warrior," wrote Glubb, "that gallant humanity which thrills us in the pages of Homer." Arabia supplanted Greece as a romantic backdrop for the enactment of Englishness, with Lawrence, as Graves noted, its Byronic figure. "There has, probably, been no English soldier so astonishing in his character and circumstances since Byron was at Missolonghi," insisted the Daily News, remarking that the two shared "the genius of literature and ... adventure." Lawrence appealed as an outsider formed by exotic experiences but also as a typically English figure, insofar as being English meant being original, eccentric, and "the mere wishing to be an Arabian betrays the roots of a quirk." Edward Said rightly claims that in this period, "the Orientalist ha[d] become the representative man of his Western culture." 103

The "Lawrence myth" and the notion of development together recuperated Britons' dearest convictions about themselves: their extraordinary ability to overcome hardship and lead with pluck, wit, and amateur skill. The image of Lawrence and his colleagues, at once inside and outside the nation and the state, brought to old formulas of heroism the new taste for unorthodox methods, suspicion of authority, and impatience with "red tape," diagnosed by Michael Paris. Lawrence's fascination with airpower and his longing for pastoral English life were

102. H. G. Wells to Lawrence, May 17, 1927, in Letters to T. E. Lawrence, 212; Satia, Spies in Arabia, 194-95.

103. Liddell Hart, "T. E. Lawrence," 386; Buchan, Memory Hold-the-Door, 212; Lawrence, The Seven Pillars of Wisdom, 259; Winterton, quoted in Kathryn Tidrick, Heart-Beguiling Araby: The English Romance with Arabia (London: Tauris Parke Paperbacks, 2010); Richard Coke, The Arab's Place in the Sun (London: Butterworth, 1929), 12 and 289; MECA, Glubb Papers, Iraq S. Desert (2), "On Bedu Dialect," draft, 1926; Graves, Lawrence and the Arabs, 57; Daily News, quoted in Wilson, Lawrence of Arabia, 783; Said, Orientalism, 246; Satia, Spies in Arabia, 195-98. 
of a piece with the at once modernist and conservative interwar visions of nation and empire-fused in the dream of a restored, yet refitted, Mesopotamia. ${ }^{104}$ If elites as far as Latin America perceived the "death-agony of Belle Époque Europe," 105 the Middle Eastern campaigns were literally theaters for the enactment of a restored European civilization, stripped of its bourgeois decadence-though this was, as we know from the rest of twentieth-century history, doomed to self-immolation. The new forms of violence introduced in the Middle Eastern campaigns foreshadowed that turn, too. Indeed, Arthur "Bomber" Harris and many other airforcemen who would play an important role in future conflicts obtained their training and experience in that region. ${ }^{106}$

Hopes for imperial redemption through the development of Arabia began to crumble almost from their inception. The occupying army built bridges and railways, drained marshes, and so on-largely to serve army and imperial administrative needs-but many of these projects were discarded because of financial stringency and because air control began to substitute for other forms of development after the Iraqi rebellion of $1920 .{ }^{107}$ The apparent abandonment of the path of imperial expiation made Mesopotamia "the burning political issue of the time," in the words of the India secretary Lord Peel. ${ }^{108}$ As a discreet and cheap instrument of colonial discipline, air control was designed to silence the fury, but as the state's actions grew more covert, the British public-like the Iraqisremained on its scent, ever imagining the worst and doubting the authenticity of their democracy. If the Middle East "sideshows" help us understand continuities with the prewar past, they also crucially illuminate interwar political paranoia and the growth of the secret state. Middle Eastern policy was central to the movement for democratic control of foreign policy, as I have shown elsewhere, and Lawrence's heroism took on a darker tincture as Britons seized on his wartime exploits as proof that the state could use a single spy to covertly pursue imperialist ends. Postwar skepticism about official news and the press was permanently reinforced by a more malevolent vision of the state than ever before, grounded in a sense of its betrayal of the promise of redemption in the Middle East. Meanwhile, the state put all this criticism down to the conspiratorial machinations of rogue Middle East veterans, cause for further expansion of the secret state at home. The spy emerged as an everyman hero in societies in which individuals felt alienated from the large organizations that dominated public life; this was the case in interwar Britain when

104. Paris, Warrior Nation, 185; Satia, Spies in Arabia, 196-98.

105. Olivier Compagnon, "1914-18: The Death Throes of Civilization. The Elites of Latin America Face the Great War," in Uncovered Fields: Perspectives in First World War Studies, ed. Jenny MacLeod and Pierre Purseigle (Leiden: Brill, 2004), 279-95.

106. Satia, Spies in Arabia, chap. 7.

107. TNA, WO 158/626, Salmond, commanding Middle East Brigade, RFG to CGS, GHQ EEF, November 12, 1916; Satia, Spies in Arabia, chap. 7.

108. William Peel, comment on Aylmer Haldane, "The Arab Rising in Mesopotamia, 1920,” November 29, 1922, JRUSI 68/469 (1923): 63-81, here p. 80. 
a stirring mass democracy came face to face with its limited purchase on the state's activities and a culture of gentlemanly reserve made the spy a peculiarly English professional. $^{109}$

By integrating the Middle Eastern campaigns into our main narrative of the Great War's cultural impact in Britain, many otherwise idiosyncratic and strange phenomena begin to make sense: British technophilia, the romance of airpower, the popularity of Lawrence, the commitment to empire, the brittle faith in mass democracy. But this wider geographical focus also destabilizes our sense of when precisely the war happened. A global perspective forces us to recognize that, despite the end of the conflict in France, the war went on into the early 1920s. Moreover, during this decade the British in the Middle East redefined warfare in a manner that would crucially shape the next world war. The Great War was indeed both larger and longer than our conventional European historiography has allowed.

\author{
Priya Satia \\ Stanford University
}

109. John G. Cawelti and Bruce A. Rosenberg, The Spy Story (Chicago: University of Chicago Press, 1987), 32; Robert Colls, "The Constitution of the English," History Workshop Journal 46 (1998): 97-127, here p. 109; Satia, Spies in Arabia, chap. 9; Satia, "Interwar Agnotology: Empire, Democracy and the Production of Ignorance," in Brave New World: Imperial and Democratic Nation-Building in Britain between the Wars, ed. Laura Beers and Geraint Thomas (London: Institute of Historical Studies, 2012), 209-26. 